\title{
Seasonal dependence of peroxy radical concentrations at a Northern hemisphere marine boundary layer site during summer and winter: evidence for radical activity in winter
}

\author{
Z. L. Fleming ${ }^{1}$, P. S. Monks ${ }^{1}$, A. R. Rickard ${ }^{1, *}$, B. J. Bandy ${ }^{2}$, N. Brough ${ }^{2}$, T. J. Green ${ }^{2}$, C. E. Reeves ${ }^{2}$, and \\ S. A. Penkett ${ }^{2}$ \\ ${ }^{1}$ Department of Chemistry, University of Leicester, Leicester, UK \\ ${ }^{2}$ School of Environmental Sciences, University of East Anglia, Norwich, UK \\ *now at: Department of Chemistry, University of Leeds, Leeds, UK
}

Received: 13 June 2006 - Published in Atmos. Chem. Phys. Discuss.: 2 August 2006

Revised: 30 October 2006 - Accepted: 23 November 2006 - Published: 5 December 2006

\begin{abstract}
Peroxy radicals $\left(\mathrm{HO}_{2}+\Sigma \mathrm{RO}_{2}\right)$ were measured at the Weybourne Atmospheric Observatory $\left(52^{\circ} \mathrm{N}, 1^{\circ} \mathrm{E}\right)$, Norfolk using a PEroxy Radical Chemical Amplifier (PERCA) during the winter and summer of 2002. The peroxy radical diurnal cycles showed a marked difference between the winter and summer campaigns with maximum concentrations of 12 pptv at midday in the summer and maximum concentrations as high as $30 \mathrm{pptv}$ (10 min averages) in winter at night. The corresponding nighttime peroxy radical concentrations were not as high in summer ( 3 pptv). The peroxy radical concentration shows a distinct anti-correlation with increasing $\mathrm{NO}_{\mathrm{x}}$ during the daylight hours. At night, peroxy radicals increase with increasing $\mathrm{NO}_{\mathrm{x}}$ indicative of the role of $\mathrm{NO}_{3}$ chemistry. The average diurnal cycles for net ozone production, $\mathrm{N}\left(\mathrm{O}_{3}\right)$ show a large variability in ozone production, $\mathrm{P}\left(\mathrm{O}_{3}\right)$, and a large ozone loss, $\mathrm{L}\left(\mathrm{O}_{3}\right)$ in summer relative to winter. For a daylight average, net ozone production in summer was higher than winter $\left(1.51 \pm 0.5 \mathrm{ppbv} \mathrm{h}^{-1}\right.$ and $1.11 \pm 0.47 \mathrm{ppbv} \mathrm{h}^{-1}$, respectively). The variability in NO concentration has a much larger effect on $\mathrm{N}\left(\mathrm{O}_{3}\right)$ than the peroxy radical concentrations. Photostationary state (PSS) calculations show an $\mathrm{NO}_{2}$ lifetime of $5 \mathrm{~min}$ in summer and 21 minutes in the winter, implying that steady-state $\mathrm{NO}-\mathrm{NO}_{2}$ ratios are not always attained during the winter months. The results show an active peroxy radical chemistry at night and that significant oxidant levels are sustained in winter. The net effect of this with respect to production of ozone in winter is unclear owing to the breakdown in the photostationary state.
\end{abstract}

\footnotetext{
Correspondence to: P. S. Monks

(p.s.monks@le.ac.uk)
}

\section{Introduction}

Peroxy radicals $\left(\mathrm{HO}_{2}\right.$ and the sum of the organic peroxy radicals, $\mathrm{RO}_{2}$ (predominantly $\mathrm{CH}_{3} \mathrm{O}_{2}$ in semi-polluted atmospheres)) represent key short-lived intermediates in atmospheric oxidation cycles. They can be thought of as being the intermediates between the $\mathrm{OH}$ radical and ozone formation or destruction (Atkinson, 2000; Heard and Pilling, 2003; Monks, 2003, 2005). Peroxy radicals are formed as the hydroxyl radical $(\mathrm{OH})$ reacts with VOCs and $\mathrm{CO}$ viz

$$
\begin{aligned}
\mathrm{O}_{3}+h v(\lambda<320 \mathrm{~nm}) & \rightarrow \mathrm{O}_{2}+\mathrm{O}\left({ }^{1} \mathrm{D}\right) \\
\mathrm{O}\left({ }^{1} \mathrm{D}\right)+\mathrm{H}_{2} \mathrm{O} & \rightarrow 2 \mathrm{OH} \\
\mathrm{CH}_{4}+\mathrm{OH} & \rightarrow \mathrm{CH}_{3}+\mathrm{H}_{2} \mathrm{O} \\
\mathrm{CH}_{3}+\mathrm{O}_{2}+\mathrm{M} & \rightarrow \mathrm{CH}_{3} \mathrm{O}_{2}+\mathrm{M} \\
\mathrm{OH}+\mathrm{CO} & \rightarrow \mathrm{H}+\mathrm{CO}_{2} \\
\mathrm{H}+\mathrm{O}_{2}+\mathrm{M} & \rightarrow \mathrm{HO}_{2}+\mathrm{M}
\end{aligned}
$$

The relative importance of ozone production and loss processes in the background troposphere is highly sensitive to competition between the reaction of peroxy radicals with NO and the peroxy self- and cross-reactions which act to terminate the radical chemistry. In the presence of $\mathrm{NO}_{\mathrm{x}}(\mathrm{NO}$ and $\mathrm{NO}_{2}$ ), the reaction of peroxy radicals with $\mathrm{NO}$, if the concentration is above a critical level (Monks, 2005), forms $\mathrm{NO}_{2}$, the subsequent photolysis of which leads to ozone production:

$$
\begin{aligned}
\mathrm{HO}_{2}+\mathrm{NO} & \rightarrow \mathrm{OH}+\mathrm{NO}_{2} \\
\mathrm{RO}_{2}+\mathrm{NO} & \rightarrow \mathrm{RO}+\mathrm{NO}_{2} \\
\mathrm{RO}+\mathrm{O}_{2} & \rightarrow \mathrm{HO}_{2}+\text { carbonyl } \\
\mathrm{NO}_{2}+h v(\lambda<424 \mathrm{~nm}) & \rightarrow \mathrm{O}\left({ }^{3} \mathrm{P}\right)+\mathrm{NO} \\
\mathrm{O}\left({ }^{3} \mathrm{P}\right)+\mathrm{O}_{2}+\mathrm{M} & \rightarrow \mathrm{O}_{3}+\mathrm{M}
\end{aligned}
$$

Published by Copernicus GmbH on behalf of the European Geosciences Union. 
In conditions of low $\mathrm{NO}_{\mathrm{x}}$, a corresponding cycle leads to net ozone destruction

$$
\begin{aligned}
\mathrm{HO}_{2}+\mathrm{O}_{3} & \rightarrow \mathrm{OH}+2 \mathrm{O}_{2} \\
\mathrm{OH}+\mathrm{CO} & \rightarrow \mathrm{H}+\mathrm{CO}_{2} \\
\mathrm{H}+\mathrm{O}_{2}+\mathrm{M} & \rightarrow \mathrm{HO}_{2}+\mathrm{M} \\
\text { Overall }: \mathrm{CO}+\mathrm{O}_{3} & \rightarrow \mathrm{CO}_{2}+\mathrm{O}_{2}
\end{aligned}
$$

The photochemical control of $\mathrm{O}_{3}$ has been linked with the relevant transport terms to explain the characteristic annual ozone cycle which shows a broad maximum in spring and a minimum in the summer months at Northern Hemisphere mid-latitude sites (Derwent et al., 1998; Monks, 2000; Monks et al., 2000; Brönnimann, 1999).

With respect to season, it has been shown that less $\mathrm{NO}_{\mathrm{x}}$ is required in winter than summer for net photochemical ozone production to occur owing to the higher water vapour concentrations and photolysis rates in summer leading to greater photochemical loss term for ozone (Klonecki and Levy, 1997; Yienger et al., 1999; Salisbury et al., 2002; Zanis et al., 2003; Reeves et al., 2003; and Stroud et al., 2004). However, few measurement campaigns have been carried out in the winter months (Penkett et al., 1999; Monks et al., 2000; Heard et al., 2004), when the sun's intensity is reduced dramatically at mid-latitudes.

Without perturbation from peroxy radicals, photodissociation of $\mathrm{NO}_{2}$ to $\mathrm{NO}$ in Eq. (10) and subsequent regeneration of $\mathrm{NO}_{2}$ via reaction of $\mathrm{NO}$ with $\mathrm{O}_{3}$ is sufficiently fast in moderately polluted air masses that these species are in a dynamic equilibrium

$$
\begin{aligned}
& \mathrm{NO}_{2}+h v(\lambda<424 \mathrm{~nm}) \rightarrow \mathrm{O}\left({ }^{3} \mathrm{P}\right)+\mathrm{NO} \\
& \mathrm{O}\left({ }^{3} \mathrm{P}\right)+\mathrm{O}_{2}+\mathrm{M} \rightarrow \mathrm{O}_{3}+\mathrm{M} \\
& \mathrm{NO}+\mathrm{O}_{3} \rightarrow \mathrm{NO}_{2}+2 \mathrm{O}_{2}
\end{aligned}
$$

A photochemical steady state, PSS (Leighton, 1961) exists provided the $\mathrm{NO}-\mathrm{NO}_{2}-\mathrm{O}_{3}$ system is isolated from local sources of $\mathrm{NO}_{\mathrm{x}}$ and sunlight is constant. In a low $\mathrm{NO}_{\mathrm{x}}$ environment, peroxy radicals perturb the $\mathrm{NO}_{2} / \mathrm{NO}$ ratio from its PSS value. Yang et al. (2004) looked at the NO- $\mathrm{NO}_{2}$ $\mathrm{O}_{3}$ photostationary state correlations of peroxy radicals with ozone and $j\left(\mathrm{NO}_{2}\right)$ using the deviation from the photostationary state as derived by Ridley et al. (1992). Under sunlit conditions, $\mathrm{NO}$ and $\mathrm{NO}_{2}$ undergo fast inter-conversion through the reaction of peroxy radicals (8) or ozone (14) with $\mathrm{NO}$ and from $\mathrm{NO}_{2}$ photolysis (10). Therefore the $\mathrm{NO}$ to $\mathrm{NO}_{2}$ ratio is dependent on the reaction of $\mathrm{NO}$ with $\mathrm{O}_{3}$ and on $j\left(\mathrm{NO}_{2}\right)$. In remote regions increased peroxy radical concentrations and their reactions with NO become more competitive with Reaction (14) (Volz-Thomas et al., 2003).

Previous research at Weybourne Atmospheric Observatory (WAO), the field site for the present study, includes the TIGER (Terrestrial Initiative in Global Environmental Research) program campaigns in April 1994 (WAOSE '94),
October/November 1994 (WAOWE '94) and May/June 1995 (WAOSE '95). One of the objectives of these studies was to study peroxy radicals formed at night via $\mathrm{NO}_{3}$ radical chemistry (Carslaw et al., 1997) and their role in the in situ photochemical production of ozone (Penkett et al., 1999).

The WAOWE '94 campaign had long periods when the air masses originated from Europe and travelled to Weybourne, passing over London. There were also periods when clean maritime Atlantic air arrived at the site. The $\mathrm{NO}_{\mathrm{x}}$ levels were up to 50 or $60 \mathrm{ppbv}$ on the polluted days and $<5 \mathrm{ppbv}$ when clean maritime air predominated. Peroxy radical levels reached were 2-4 pptv at night and dropped to zero between dawn and dusk (These values are uncorrected for water dependency (see experimental); Carpenter et al., 1998; and Clemitshaw et al., 1997). The high variability of ozone at this time, meant that the background variability in the peroxy radical data was so great that a large proportion of the data had to be discarded.

During the WAOSE ' 95 campaign the site mainly received air masses from the Arctic and the tropics, that had very low ozone levels. A few days received polluted air that had travelled over polluted locations in Britain or even Holland. The summer measurements yielded higher peroxy radical concentrations during the day, up to 13 pptv, and night-time levels as high as 9 pptv on occasion (These values are uncorrected for water dependency (see experimental); Carpenter et al., 1998; and Clemitshaw et al., 1997). Daytime concentrations were generally 2 to 3 times greater than night-time values. However, some nights had concentrations as high or even higher than during the day and signalled a major nighttime peroxy radical forming mechanism.

Penkett et al. (1999) reported that NO concentrations were higher, peroxy radicals lower and ozone was more variable in winter than in summer. A correlation of peroxy radicals with ozone and PAN was noted on a few days, and this provided evidence of peroxy radicals being key intermediates in photochemical ozone production and the formation of PAN. The presence of a double peak in the peroxy radical diurnal cycle, due to $\mathrm{HO}_{2}$ production from $\mathrm{OH}$ radical chemistry, was noted during the day, producing a maximum at solar noon and then a second peak due to a production mechanism in the early evening.

Allan et al. (1999) found that the $\mathrm{NO}_{3}$ radical chemistry occurring at night led to peroxy radical formation, and Carslaw et al. (1997) observed a positive correlation between $\mathrm{NO}_{3}$ and peroxy radicals measured at night.

In this paper, we report on $\mathrm{HO}_{2}+\Sigma \mathrm{RO}_{2}$ measurements using a state of the art dual-channel chemical amplification technique (PERCA) combined with measurements of $\mathrm{NO}_{\mathrm{x}}$, $\mathrm{CO}, \mathrm{CH}_{4}, \mathrm{O}_{3}$, condensation nuclei $(\mathrm{CN})$ counts, photolysis frequencies and meteorological parameters for two campaigns at the same site (Weybourne, north Norfolk) during both winter and summer. A comparison of a variety of chemical and physical parameters has been made, especially with respect to peroxy radicals to see how the two seasons can 
dictate the form of the radical diurnal cycle, the radical formation pathway and the absolute concentrations measured. The ability to make ozone with season is explored.

\section{Experimental}

\subsection{Site}

The Weybourne Atmospheric Observatory (Clemitshaw and Penkett, 1994; Penkett et al., 1999) is situated on the north Norfolk coast of England ( $\left.52^{\circ} 57^{\prime} 23^{\prime \prime} \mathrm{N}, 1^{\circ} 7^{\prime} 40^{\prime \prime} \mathrm{E}\right)$ at an altitude of $16 \mathrm{~m}$ above sea level. Set up in 1992, the observatory is located in a converted World War II Gunnery Blockhouse, containing an instrument room housing a variety of continuously running instruments for measuring trace gases, and a meteorological station. A ten-metre scaffolding tower fixed to the seaward side of the observatory is used for the trace gas sampling inlets.

The WAO has an open seaward fetch of 30 degrees bounded by the coasts of England and Scotland and the west coast of Norway, with a clear view across the North Sea to the Arctic Ocean and Bering Sea beyond (see Fig. 1). The air encountered at this site is normally clean in spring and summer but less so in winter. Air masses also travel from European southerly latitudes and pollution can be carried here from nearby cities in Britain (with Norwich $49 \mathrm{~km}$ and London $193 \mathrm{~km}$ away). The county of Norfolk consists primarily of flat, arable farmland with several small coniferous and deciduous forests, and the coastline is a mixture of pebble and sand beaches.

The winter campaign, termed WAOWEX (Weybourne Atmospheric Observatory Winter EXperiment) was a smallscale campaign (from 27 January to the 8 February 2002) using exclusively instruments from the University of Leicester and the University of East Anglia (UEA). All instruments were controlled within the main laboratory and the inlets were all placed on the permanent $10 \mathrm{~m}$ tower. The spectral radiometer was situated at ground level on the grass towards the seaward side of the laboratory, out of any shading from the building.

The summer campaign was held from the 15 September to 3 October 2002 as part of a large European collaboration called INSPECTRO (INfluence of clouds on the SPECtral actinic flux in the lower TROposphere) (Monks et al., 2004) was set up to investigate the effect of clouds on solar flux. The PERCA, $\mathrm{NO}_{\mathrm{xy}}$, filter radiometers, spectral radiometer and temperature and humidity probe were all set up on a temporary building on the hardcore outside the main building. The inlet boxes and radiometry were all placed 5 metres above ground level, on a tower on top of this temporary building.

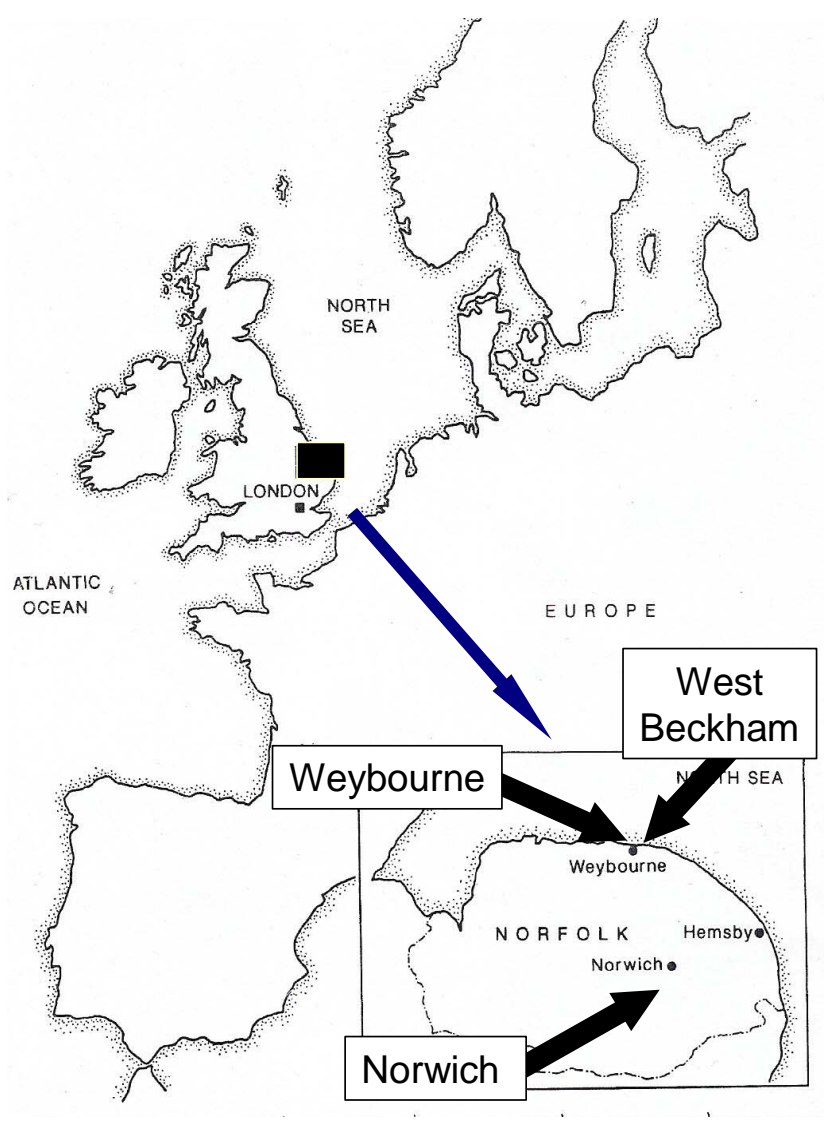

Fig. 1. Location of Weybourne Atmospheric Observatory, Norfolk, UK (adapted from Cardenas et al., 1998).

\subsection{Peroxy radical measurements (PERCA)}

Measurements of peroxy radicals $\left(\mathrm{HO}_{2}+\Sigma \mathrm{RO}_{2}\right)$ were carried out using the jointly operated Leicester University University of East Anglia (UEA) PERCA IV instrument. The PEroxy Radical Chemical Amplifier was pioneered by Cantrell et al. (1984) and described by Clemitshaw et al. (1997) and more recently Monks et al. (1998), Salisbury (2001) and Green et al. (2003). The PERCA IV instrument has a dual channel inlet and detection system the principle of which was first described by Cantrell et al. (1996) and is described in detail for this specific instrument in Green et al. (2006). A full description of the principle of operation of PERCA IV can be found in Fleming et al. (2006).

Mihele et al. $(1998,1999)$ have shown that the chain length of a chemical amplifier is reduced in the presence of atmospheric water vapour. Salisbury et al. (2002) showed that the chain length of the Leicester-UEA PERCA II instrument falls approximately linearly with increasing specific humidity $(Q)$ and from a series of laboratory experiments, a humidity correction factor $(\mathrm{CF})$ equation (using ambient humidity and the inlet temperature) was derived to multiply all PERCA data 


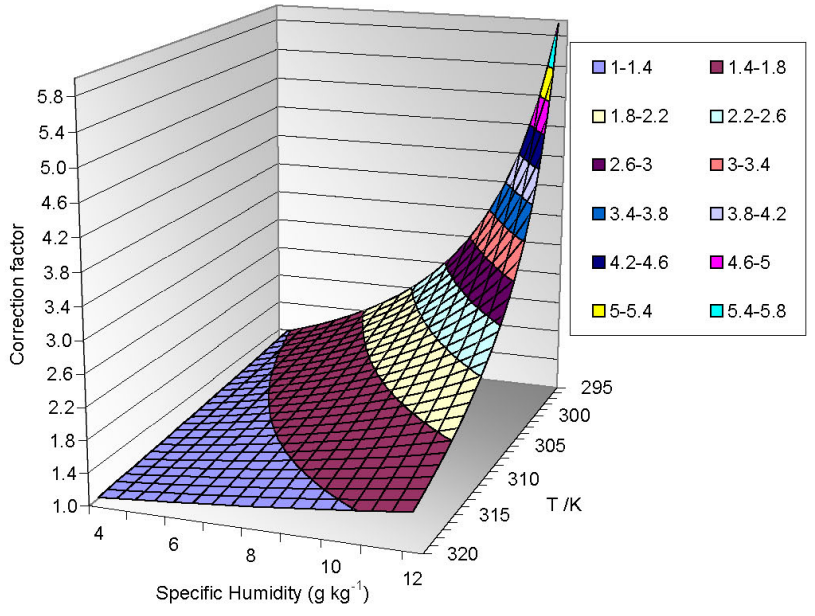

Fig. 2. The variation of the derived water correction factor, applied to $\mathrm{HO}_{2}+\Sigma \mathrm{RO}_{2}$ PERCA data, with specific humidity and temperature (after Salisbury et al., 2002).

by:

$$
C F=100 /\left(\left(0.17 * T_{\text {inlet }}-57.08\right) * Q+99.96\right)
$$

where the inlet temperature, $\mathrm{T}_{\text {inlet }}$ was kept close to $30^{\circ} \mathrm{C}$ and the specific humidity $(\mathrm{g} / \mathrm{kg})$ was calculated from ambient relative humidity measurements.

Figure 2 shows the form of the water correction factor as applied to the measured peroxy radical data. The correction factor increases as the humidity increases and as the temperature of the inlet system decreases. The inlets were operated at a temperature of $30^{\circ} \mathrm{C}$ to minimise the magnitude of the applied correction factor. The uncertainty in the PERCA measurements is about $42 \%$. The sources of error and estimated magnitude of error are as follows: Radical calibration $\left(j\left(\mathrm{CH}_{3} \mathrm{I}\right)\right.$ measurement $(15 \%)$, mass flow controller calibration (zero air and $\left.\mathrm{CH}_{3} \mathrm{I}\right)(5 \%), \mathrm{CH}_{3} \mathrm{I}$ permeation tube leak $(5 \%)$, volume of photolysis cell $(5 \%)), \mathrm{NO}_{2}$ detection (background variability (10\%), thermal instability of luminol $(20 \%)$ and the water correction factor error $(20 \%))$. This gives an uncertainty value of $18 \%$ for radical calibration and $22.4 \%$ for $\mathrm{NO}_{2}$ calibration. Therefore, the overall radical measurement uncertainty is $42 \%$ (updated from Fleming et al., 2006).

\subsection{Supporting measurements}

Ozone $\left(\mathrm{O}_{3}\right)$ measurements were carried out with a Thermo Environment model $49 \mathrm{O}_{3}$ analyser (which utilises ultraviolet photometry at $\lambda=253.7 \mathrm{~nm}$ ) with a detection limit of ca. 1 ppbv. Carbon monoxide (CO) measurements were taken using a Trace Analysis RGA-3 Reduced Gas Analyser as described by Cardenas et al. (1998). Condensation nuclei $(\mathrm{CN})$ counts were monitored with a TSI model 3022A counter (cut-off size 0.007 microns) and a TSI model 3010 counter (cut-off size 0.01 microns). The meteorological data were obtained by an automatic meteorological station which recorded ambient air temperature, relative humidity, wind speed, wind direction, direct and diffuse solar irradiance. Relative humidity and temperature were recorded using a MP103A (Campbell Scientific Ltd.) attached to the inlet scaffold during the summer campaign and at the meteorological station approximately $10 \mathrm{~m}$ away at a height of $2 \mathrm{~m}$.

\section{$2.4 \quad \mathrm{NO}_{\mathrm{x}} / \mathrm{NO}_{\mathrm{y}}$}

The UEA $\mathrm{NO}_{\mathrm{x}}$ and $\mathrm{NO}_{\mathrm{y}}\left(\mathrm{NO}_{\mathrm{xy}}\right)$ instrument was deployed for continuous $\mathrm{NO}_{\mathrm{x}}\left(\mathrm{NO}+\mathrm{NO}_{2}\right)$ and $\mathrm{NO}_{\mathrm{y}}$ (Total oxidised Nitrogen: $\mathrm{NO}_{\mathrm{x}}+\mathrm{NO}_{z}$, where $\mathrm{NO}_{z}$ is $\mathrm{PAN}+\mathrm{HNO}_{3}+\mathrm{RNO}_{3}+\mathrm{N}_{2} \mathrm{O}_{5}+\mathrm{NO}_{3}$ ) measurements. This used a chemiluminescence technique, where the light was measured by a cooled, red-sensitive photomultiplier tube as described in Brough et al. (2003). The sampled air was mixed with humidified ozone in the reaction vessel and calibration was carried out using a standard concentration of $\mathrm{NO}$ in $\mathrm{N}_{2}$. The detection limit $(2 \sigma)$ for the NO measurements was calculated to be $1-2$ pptv on a one minute average with an estimated accuracy of $\pm 8 \%$ at the 50 pptv level.

\subsection{Photolysis rate coefficients}

Two $j\left(\mathrm{O}^{1} \mathrm{D}\right)$ (the photolysis rate coefficient for the photolysis of $\mathrm{O}_{3}$ (Reaction 1) and one $j\left(\mathrm{NO}_{2}\right)$ fixed bandwidth filter radiometers (FR) were used to determine specific photolysis rate coefficients (Shetter et al., 2003; Hofzumahaus et al., 2004). A single-monochromator diode array Spectral Radiometer (SR) was used to measure atmospheric actinic flux (Edwards and Monks, 2003; Monks et al., 2004; and Seroji et al., 2004). Combining of the measured actinic flux with the relevant molecular parameters yields a variety of molecular photolysis frequencies including $j\left(\mathrm{O}^{1} \mathrm{D}\right), j\left(\mathrm{NO}_{2}\right)$, $j(\mathrm{HONO})$ and $j(\mathrm{HCHO})$.

Outputs from the filter radiometers and spectral radiometer were obtained every second and averaged into minute time series. $j\left(\mathrm{O}^{1} \mathrm{D}\right)$ uncertainties from the SR data were are $13 \%$ and for $j\left(\mathrm{NO}_{2}\right) 14 \%$ (Edwards and Monks, 2003). $j\left(\mathrm{O}^{1} \mathrm{D}\right)$ photolysis frequencies were taken from the spectral radiometer whenever possible, but the good comparison between this and the FRs allowed for rare gaps in the SR data to be fitted.

\section{Results and discussion}

\subsection{Meteorological conditions}

The meteorological data comprises the relative humidity and temperature data and the Weybourne meteorological station's wind speed and wind direction data. These were averaged into hourly data and assigned a predominant wind direction. Five-day back trajectories were also obtained from 
the British Atmospheric Data Centre (http://badc.nerc.ac.uk). The ECMWF back trajectories were calculated for every $6 \mathrm{~h}$ arriving at $950 \mathrm{hPa}$ in a $50 \mathrm{~km}$ cluster around WAO.

Figure 3 shows histograms of all the hourly wind directions reaching Weybourne during the winter and summer campaigns. During the summer campaign, the majority of air masses were from a north-easterly (NE) direction (between 20 and $80^{\circ}$ ) with another strong section from a southwesterly (SW) direction (between 230 and $250^{\circ}$ ). A value of $3 \mathrm{~ms}^{-1}$ was used as the cut-off wind speed, below which there is stagnant circulation. Therefore, winds $<3 \mathrm{~ms}^{-1}$ were not included in the analysis. During the winter campaign, all wind directions were between 210 and $350^{\circ}$, i.e. from a westerly (W/SW) direction, with $85 \%$ of all hourly wind directions between 240 and $300^{\circ}$. Air mass divisions for the prevailing summer conditions were made by a comparison of the back trajectories and measured wind directions throughout the campaign, resulting into a division of four sectors. The four wind sectors that represent air of varying composition and origin used for the summer are detailed in Table 1, and typical back trajectories are shown in Fig. 4. These were: northerly (N) marine air (17-22 (morning) September), easterly (E) air masses from over Scandinavia and the Baltic Sea (22 (afternoon)-24 September), northwesterly (NW) continental air from over northern Britain (25-28 (midday) September) and south-westerly (SW) that arose when northerly trajectories turned northwards a few hours before reaching Weybourne and passed over northern Europe and southern England (28-29 September). The SW sector (especially for the last few hours of the trajectory) can be compared to the winter data, where all the air masses passed over southern England before reaching Weybourne. The winter data was not divided according to wind direction or trajectories because of its relatively invariant air mass origin. The typical origin of the winter air masses are shown in Fig. 4. These mainly originate in the Atlantic Ocean or from Canada and travelled up to Weybourne through southwest Britain (Cornwall or South Wales) or through Ireland and the Midlands. Some air from a southerly origin also past over the Portuguese coast and over part of Western Europe before reaching the south of England.

\subsection{Winter and summer campaign chemical conditions}

The summer and winter campaign profiles of peroxy radicals, $j\left(\mathrm{O}^{1} \mathrm{D}\right)$ and $\mathrm{NO}_{\mathrm{x}}$ are shown in Fig. 5. Unfortunately, gaps in $\mathrm{NO}_{\mathrm{xy}}$ data mean that the analysis was carried out only on those days that had $\mathrm{NO}_{\mathrm{xy}}$ data. There is more peroxy radical variation within each day in winter than there is in summer, as well as more day-to-day variation. Peroxy radical concentrations show a larger range in winter and reached peak concentrations of over $25 \mathrm{pptv}$, compared to the lower summer peak concentrations of just over 10 pptv. Table 1 shows the average ozone, relative humidity $(\mathrm{RH})$, temperature, $\mathrm{NO}$, $\mathrm{NO}_{2}, \mathrm{NO}_{\mathrm{x}}$ and $\mathrm{HO}_{2}+\Sigma \mathrm{RO}_{2}$ values for the four air-mass
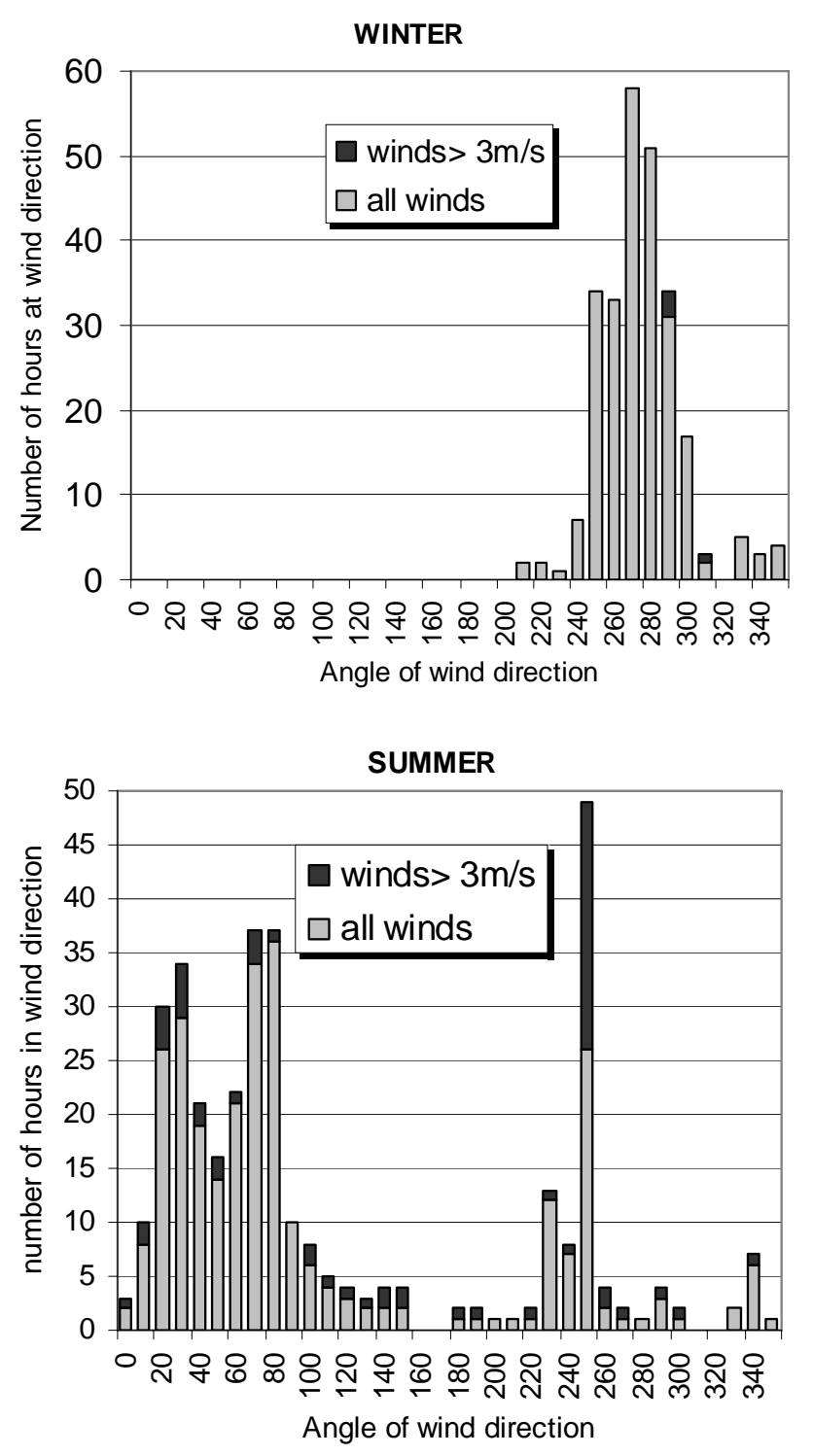

Fig. 3. Hourly averaged wind direction histograms for both the summer and winter campaigns showing the number of hours with wind directions within a 10 degree division. The extra few hours that were $<3 \mathrm{~ms}^{-1}$ are added in black. Only the grey values $\left(>3 \mathrm{~ms}^{-1}\right)$ were used in the analysis.

divisions of the summer and all the winter data. The average peroxy radical concentration in winter $(7.6 \mathrm{pptv})$ is approximately double that of each sector in summer (3.2 to $4.0 \mathrm{pptv})$. The high standard deviation in winter reflects the large peroxy radical variability. The winter conditions display greater diurnal variability than in summer, with low levels during the day and elevated night-time levels. In summer, the $\mathrm{N}$ and E sectors have higher ozone concentrations $(>40 \mathrm{ppbv})$ and lower $\mathrm{NO}_{\mathrm{x}}(<1.1 \mathrm{ppbv})$ concentrations than the other summer sectors and the winter data. It can be assumed that 


\section{SUMMER}

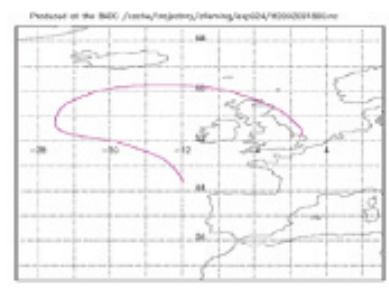

Northerly Marine

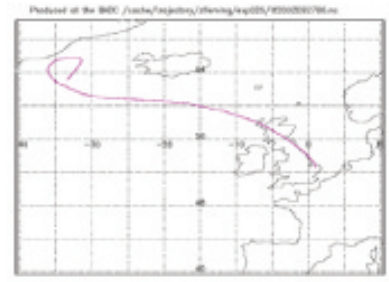

North-westerly Continental

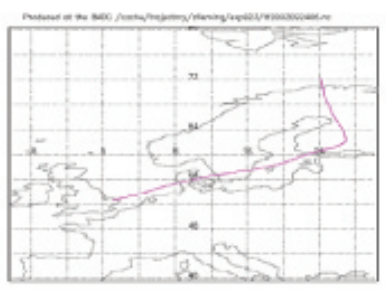

Easterly

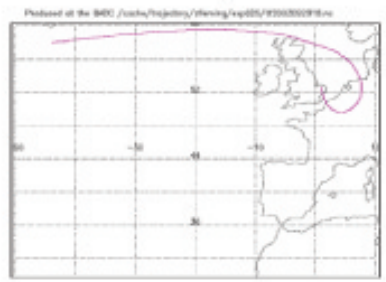

South-westerly

WINTER
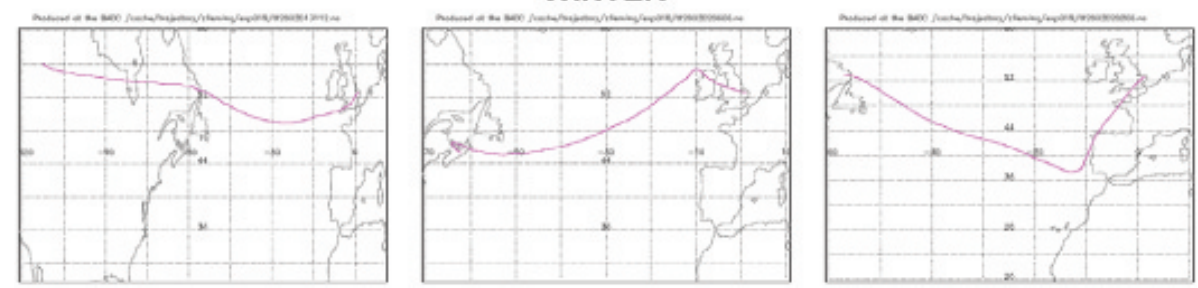

Fig. 4. Typical back trajectories representing the four air mass sector divisions applied to the summer data and three typical winter air mass origins. See text for details.
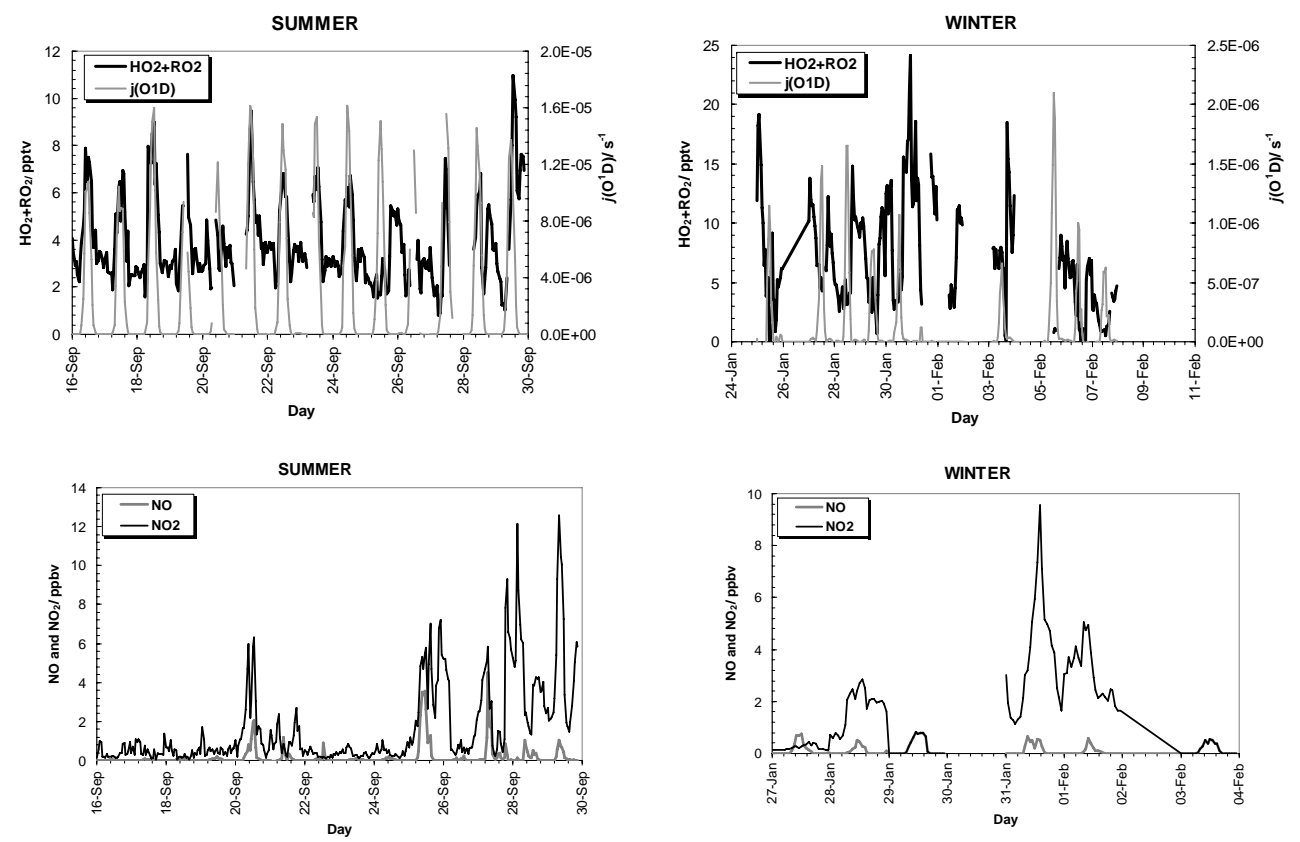

Fig. 5. Campaign profiles of $\left(\mathrm{HO}_{2}+\Sigma \mathrm{RO}_{2}\right), j\left(\mathrm{O}^{1} \mathrm{D}\right)$ and $\mathrm{NO}$ and $\mathrm{NO}_{2}$ (hourly averaged data). 
Table 1. Daily averages of selected tracers sorted by air mass sector.

\begin{tabular}{llllllll}
\hline Season and air-mass sector & $\mathrm{HO}_{2}+\Sigma \mathrm{RO}_{2} \backslash \mathrm{pptv}$ & $\mathrm{O}_{3} \backslash \mathrm{ppbv}$ & $\mathrm{NO} \backslash \mathrm{ppbv}$ & $\mathrm{NO}_{2} \backslash \mathrm{ppbv}$ & $\mathrm{NO}_{\mathrm{x}} \backslash \mathrm{ppbv}$ & $\mathrm{RH} \backslash \%$ & $\mathrm{~T} \backslash{ }^{\circ} \mathrm{C}$ \\
\hline Summer N & $3.9(1.7)$ & $45(4)$ & 0.11 & $0.92(1.1)$ & $1.03(1.4)$ & $75(6)$ & $14(0.9)$ \\
Summer E & $4.0(1.5)$ & $44(2)$ & 0.04 & $0.34(0.2)$ & $0.39(0.2)$ & $70(6)$ & $14(0.6)$ \\
Summer NW & $3.2(1.6)$ & $37(8)$ & 0.41 & $3.16(2.6)$ & $3.57(2.9)$ & $78(9)$ & $13(2.3)$ \\
Summer SSW & $3.7(2.3)$ & $34(9)$ & 0.21 & $4.66(3.0)$ & $4.88(3.3)$ & $83(11)$ & $12(3.0)$ \\
Winter all (mostly SW) & $7.6(4.6)$ & $34(5)$ & $0.14(0.2)$ & $1.58(1.7)$ & $1.72(1.8)$ & $83(7)$ & $10(2.0)$ \\
\hline
\end{tabular}

Figures in brackets are $1 \sigma$ standard deviations.

these sectors represent cleaner air masses and as such have slightly higher peroxy radical concentrations. The winter average $\mathrm{NO}_{\mathrm{x}}$ of $1.72 \mathrm{ppbv}$ is more polluted than both the summer clean sectors (with 0.39 and 1.02 ppbv average), but in winter, on average, the peroxy radical concentration is much higher. The summer continental NW and SSW sectors have average $\mathrm{NO}_{\mathrm{x}}$ concentrations $>2$ ppbv, but this does not significantly reduce peroxy radical levels, as the elevated $\mathrm{NO}_{\mathrm{x}}$ concentrations are generally in the form of short-lived spikes. Comparing the winter and summer SW air masses, there is much more $\mathrm{NO}_{\mathrm{x}}$ in summer and often twice as many peroxy radicals in winter. Table 2 shows daylight average concentrations for the many of the same parameters as Table 1 along with $j\left(\mathrm{O}^{1} \mathrm{D}\right)$. The daylight peroxy radical concentrations do not vary significantly between wind sectors in summer. It is worth noting the factor of 10 difference between summer and winter $j\left(\mathrm{O}^{1} \mathrm{D}\right)$ values. Table 3 shows the similar nighttime only concentrations. In summer, night time $\mathrm{HO}_{2}+\Sigma \mathrm{RO}_{2}$ concentrations vary little from sector to sector and show less variation than the corresponding daylight concentrations. It is clear that more peroxy radicals are formed at night in winter compared to summer. These results may be compared to measurements described by Carpenter et al. (1998) from Weybourne in winter 1993 and 1994. In winter 1993, $\mathrm{NO}_{2}$ concentrations between 2 and 33 ppbv were recorded (much larger than seen in 2002) with the highest $\mathrm{NO}_{2}$ levels present in air arriving from Europe. These high $\mathrm{NO}_{\mathrm{x}}$ air masses had very low peroxy radical concentrations. However, the winter 1994 Weybourne measurements had lower $\mathrm{NO}_{\mathrm{x}}$ concentrations than in 1993 and peroxy radical levels as high as 30 pptv. These peroxy radical concentrations have not been water corrected (see experimental) so cannot easily be quantitatively compared to the current work.

Penkett et al. (1999) from winter-summer 1994-1995 Weybourne measurements, reported that NO concentrations were higher, peroxy radicals lower and ozone was more variable in winter than in summer. From the measurements taken in 1994-1995 (where again no humidity correction was taken into account), the peroxy radicals in winter were only clearly positive at night but variations of $\mathrm{O}_{3}$ and PAN would suggest that peroxy radicals were indeed present at all times of the day but below the detection limit of the earlier instrument

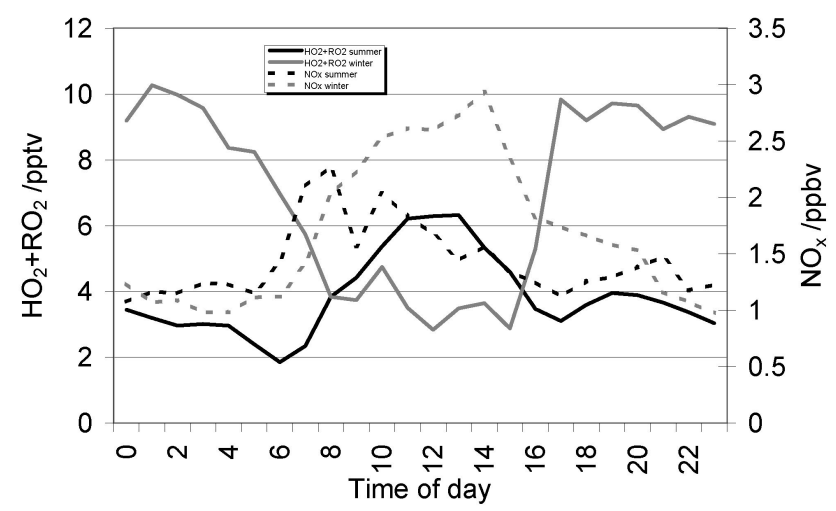

Fig. 6. Comparison of winter and summer average diurnal cycles for $\mathrm{NO}_{\mathrm{x}}$ and $\left(\mathrm{HO}_{2}+\Sigma \mathrm{RO}_{2}\right)$.

(between $0.2-1$ pptv on a $30 \mathrm{~min}$ average). In the present work, $\mathrm{NO}_{\mathrm{x}}$ concentrations were usually lower in winter than in summer.

\subsection{Diurnal variations of peroxy radicals}

Figure 6 shows the hourly averaged peroxy radical diurnal cycle for the winter and summer data. It demonstrates the contrasting shape of the diurnal peroxy radical cycle (winter vs. summer) and the differing hourly average values. Hourly averaged campaign diurnal cycles for winter and summer of peroxy radicals with $j\left(\mathrm{O}^{1} \mathrm{D}\right), \mathrm{NO}_{\mathrm{x}}$ and ozone with $\mathrm{O}_{\mathrm{x}}\left(\mathrm{NO}_{\mathrm{x}}\right.$ $+\mathrm{O}_{3}$ ) are shown in Fig. 7, with the corresponding standard deviations. $\mathrm{NO}_{\mathrm{x}}$ has a much more structured average diurnal cycle in winter, with maximum concentrations at midday. Ozone and $\mathrm{O}_{\mathrm{x}}$ are much more structured in summer, with a maximum in the afternoon.

In summer, the hourly-averaged diurnal cycle maximum $\mathrm{HO}_{2}+\Sigma \mathrm{RO}_{2}$ concentration (at midday) was only 6 pptv. The maximum hourly concentration of $12 \mathrm{pptv}$ was around midday and the night-time maximum (at 19:00) was 8 pptv. The variation in peroxy radical levels between all the days was much lower at night, particularly after 10:00 p.m. The concentrations of $\mathrm{NO}_{\mathrm{x}}$ tended to be higher in the earlier part of the day, whereas ozone concentrations peaked towards the late afternoon, as expected in summer. 
Table 2. Daylight (08:00-16:00 in winter and 06:00-19:00 in summer) averages of selected tracers sorted by air mass sector.

\begin{tabular}{llllllll}
\hline $\begin{array}{l}\text { Season and air- } \\
\text { mass sector }\end{array}$ & $\begin{array}{l}\mathrm{HO}_{2}+\Sigma \mathrm{RO}_{2} \\
\backslash \mathrm{pptv}\end{array}$ & $\begin{array}{l}\mathrm{O}_{3} \\
\backslash \mathrm{ppbv}\end{array}$ & $\begin{array}{l}\mathrm{NO} \\
\backslash \mathrm{ppbv}\end{array}$ & $\begin{array}{l}\mathrm{NO}_{2} \\
\backslash \mathrm{ppbv}\end{array}$ & $\mathrm{NO}_{\mathrm{x}} \backslash \mathrm{ppbv}$ & $\begin{array}{l}j\left(\mathrm{O}^{1} \mathrm{D}\right) \\
\backslash \mathrm{s}^{-1}\end{array}$ & $\begin{array}{l}j\left(\mathrm{NO}_{2}\right) \\
\backslash \mathrm{s}^{-1}\end{array}$ \\
\hline Summer N & $4.6(2.1)$ & $44(5)$ & 0.21 & 1.13 & $1.34(1.8)$ & 4.6 \\
Summer E & $4.7(1.7)$ & $44(2)$ & 0.07 & 0.31 & $0.38(0.3)$ & 6.2 \\
Summer NW & $3.1(1.8)$ & $37(6)$ & 0.72 & 2.32 & $3.04(3.0)$ & 5.7 \\
Summer S-SW & $4.0(3.0)$ & $32(11)$ & 0.39 & 6.21 & $6.61(3.6)$ & 5.4 & 2.84 \\
& & & & & & \\
Summer average & $4.1(2.1)$ & $40(8)$ & 0.4 & 2.49 & $2.84(2.1)$ & 5.4 & \\
Winter (PSS) & $3.7(2.1)$ & $39(3)$ & 0.25 & 2.59 & $2.85(0.7)$ & 0.67 & \\
Winter (non-PSS) & $5.2(1.9)$ & $34(2)$ & 0.43 & 0.33 & $0.77(0.3)$ & 0.46 & \\
Winter average & $4.6(1.7)$ & $33(4)$ & 0.36 & 1.25 & $1.61(1.1)$ & 0.53 \\
\hline
\end{tabular}

Figures in brackets are $1 \sigma$ standard deviations.

Table 3. Night-time averages for selected trace species by air mass sector.

\begin{tabular}{lllllll}
\hline Season and air-mass sector & $\mathrm{HO}_{2}+\Sigma \mathrm{RO}_{2} \backslash \mathrm{pptv}$ & $\mathrm{O}_{3} \backslash \mathrm{ppbv}$ & $\mathrm{NO}_{2} \backslash \mathrm{ppbv}$ & $\mathrm{NO}_{\mathrm{x}} \backslash \mathrm{ppbv}$ & $\mathrm{RH} \backslash \%$ & $\mathrm{~T} \backslash{ }^{\circ} \mathrm{C}$ \\
\hline Summer N & $3.1(0.6)$ & $44(3)$ & $0.69(0.4)$ & $0.69(0.4)$ & $77(5)$ & $14(0.9)$ \\
Summer E & $3.3(0.4)$ & $43(1)$ & $0.39(0.2)$ & $0.39(0.2)$ & $72(7)$ & $14(0.5)$ \\
Summer NW & $3.3(1.2)$ & $30(8)$ & $4.18(2.8)$ & $4.18(2.8)$ & $84(8)$ & $11(2.2)$ \\
Summer S-SW & $3.4(1.3)$ & $29(4)$ & $2.83(0.7)$ & $2.83(0.7)$ & $92(3)$ & $10(1.9)$ \\
Winter all (mostly SW) & $9.3(4.4)$ & $33(14)$ & $1.35(1.3)$ & $1.35(1.3)$ & $84(7)$ & $9(1.9)$ \\
\hline
\end{tabular}

Figures in brackets are $1 \sigma$ standard deviations.

A peroxy radical afternoon shoulder on the diurnal cycle has been noted at many locations including at Weybourne in summer 1995 by Penkett et al. (1999) and Clemitshaw et al. (1997). This shoulder suggests the photolysis of a substance at a higher wavelength than ozone. This higher wavelength photolysis becomes the predominant peroxy radical formation mechanism in the late afternoon. Yang et al. (2002) noted significant afternoon peroxy radical formation from formaldehyde photolysis in Summit, Greenland. Solberg et al. (2001) found that formaldehyde concentrations at Mace Head, Ireland and at two stations in Germany and Norway were highest in the summer and that the amount of formaldehyde photolysed was also higher in the summer. Both Burkert et al. (2003), during the INDOEX (INDian Ocean EXperiment) and Hernández et al. (2001), during the AEROSOLS99 campaign in the Atlantic ocean found the broad $\mathrm{RO}_{2}$ diurnal cycle to coincide with increased amounts of formaldehyde.

A characteristic dip in summer peroxy radical levels between daytime and nighttime (at 06:00 and again at 17:00) is observed. $\mathrm{NO}_{3}$ is photolysed in the red region of the spectrum, so photolysis is still high in the early morning and late afternoon when $j\left(\mathrm{O}^{1} \mathrm{D}\right)$ is at zero and $\mathrm{NO}_{3}$ chemistry is not yet occurring. At this time photochemical $\mathrm{OH}$ production ceases and radical levels tend to drop (more dramatically in the early morning than the evening).

The shape of the winter peroxy radical diurnal cycle strongly contrasts to that seen in summer. The maximum hourly averaged peroxy radical concentration in winter was 10 pptv (during the night) and the concentrations during daylight hours were much lower (between 3 and 5 pptv), though individual night-time hourly concentrations reached as high as 25 pptv (twice as high as the maximum hourly concentration in summer) on the 30 January.

The winter peroxy radical diurnal cycle in Fig. 6, with very low daytime concentrations and little daytime structure, does not reflect the recent findings of Heard et al. (2004) for $\mathrm{HO}_{2}$ in the urban highly polluted winter atmosphere. Here ozonealkenes and the photolysis of carbonyls were implicated in the initiation and propagation of significant daytime $\mathrm{OH}$ and $\mathrm{HO}_{2}$ levels in winter.

There was no obvious shape to the winter ozone diurnal cycle in Fig. 7 and the standard deviation between the days was up to 6 ppbv. Ozone concentrations were lower in winter with averages varying between $30-34$ ppbv (37-44 ppbv in summer).

When considering the shape of the tracer diurnal cycles no account has been made of any potential effects of local 

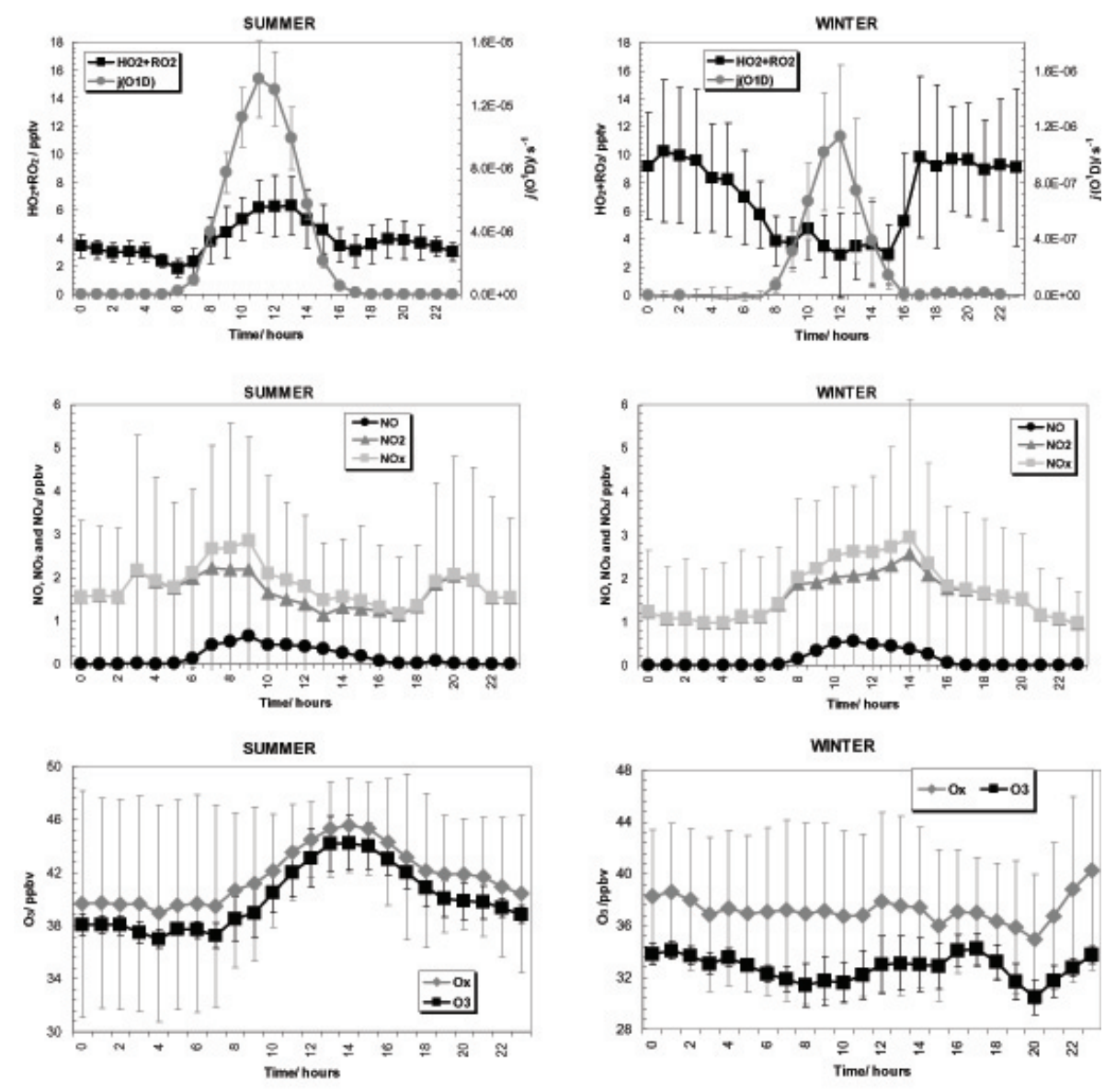

Fig. 7. Campaign hourly averages showing diurnal cycles of peroxy radicals and $j\left(\mathrm{O}^{1} \mathrm{D}\right)$ (note factor of 10 difference in scale between winter and summer), $\mathrm{NO}_{\mathrm{x}}$ (and $\mathrm{NO}$ and $\left.\mathrm{NO}_{2}\right)$ and $\mathrm{O}_{3}$ and $\mathrm{O}_{\mathrm{x}}\left(\mathrm{NO}_{2}+\mathrm{O}_{3}\right)$ for summer and winter. The bars represent $1 \sigma$ standard deviation.

meteorology e.g. land-sea breezes or changing boundary layer height. Inspection of the wind speed/direction data shows that the $3 \mathrm{~ms}^{-1}$ wind-speed screen effectively removes the few sea-breezes evident in summer.

\subsection{Peroxy radical and $\mathrm{NO}_{\mathrm{x}}$ relationships}

Figure 8 shows the peroxy radical dependence on $\mathrm{NO}_{\mathrm{x}}$ concentrations for the summer and winter. Summer data was sorted according to three differing levels of $j\left(\mathrm{O}^{1} \mathrm{D}\right)$ These were strong sunlight: $j\left(\mathrm{O}^{1} \mathrm{D}\right)$ $>7.5 \times 10^{-6}$, low solar intensity (mostly mornings and evenings): $3 \times 10^{-7}>j\left(\mathrm{O}^{1} \mathrm{D}\right)>7.5 \times 10^{-6}$ and night-time: $\left.j\left(\mathrm{O}^{1} \mathrm{D}\right)<3 \times 10^{-7}\right)$. Winter data was simply divided into day and night, with $j\left(\mathrm{O}^{1} \mathrm{D}\right)<3 \times 10^{-7}$ as the cut-off value (all values of $j\left(\mathrm{O}^{1} \mathrm{D}\right)$ have units of $\left.\mathrm{s}^{-1}\right)$. In summer daylight hours (Fig. 8a), as $\mathrm{NO}_{\mathrm{x}}$ increases, peroxy radical concentration decreases. At $\mathrm{NO}_{\mathrm{x}}$ concentrations from ca. 1-1.2 ppbv, the decreasing radical levels expected, as $\mathrm{NO}_{\mathrm{x}}$ increases, are no longer observed, hinting that the air mass type has moved from the $\mathrm{NO}_{\mathrm{x}}$-limited regime to the VOC-sensitive regime
(Sillman and $\mathrm{He}, 2002$ ). Above $\mathrm{NO}_{\mathrm{x}}$ values of $1.2 \mathrm{ppbv}$ the radicals continue to decrease.

The winter $\mathrm{HO}_{2}+\Sigma \mathrm{RO}_{2}$ data (Fig. 8b) for daylight hours have corresponding $\left[\mathrm{NO}_{\mathrm{x}}\right]>0.7 \mathrm{ppbv}$, and little peroxy radical variation was seen over this narrow $\mathrm{NO}_{\mathrm{x}}$ range, except for a gradual decrease.

At night, in the summer, the peroxy radicals show little influence from $\mathrm{NO}_{\mathrm{x}}$ below $1 \mathrm{ppbv}$, but for $\mathrm{NO}_{\mathrm{x}}$ greater than 2 ppbv the peroxy radical concentrations tend to be higher than the radical concentrations at lower $\mathrm{NO}_{\mathrm{x}}$ levels. This is suggestive of peroxy radical production from $\mathrm{NO}_{3}$ chemistry. For winter night-time values above $1 \mathrm{ppbv} \mathrm{NO}_{\mathrm{x}}$, the peroxy radicals, as in summer, are higher than at lower $\mathrm{NO}_{\mathrm{x}}$ concentrations.

Figure $8 \mathrm{c}$ is a plot of daytime peroxy radical concentrations in winter and summer against binned NO. In summer, the trend is not dissimilar to the $\mathrm{NO}_{\mathrm{x}}$ trend. However, in winter, any peroxy radical-NO trend breaks down completely. This observation will be discussed later with respect to the calculated ozone production. 
(A)

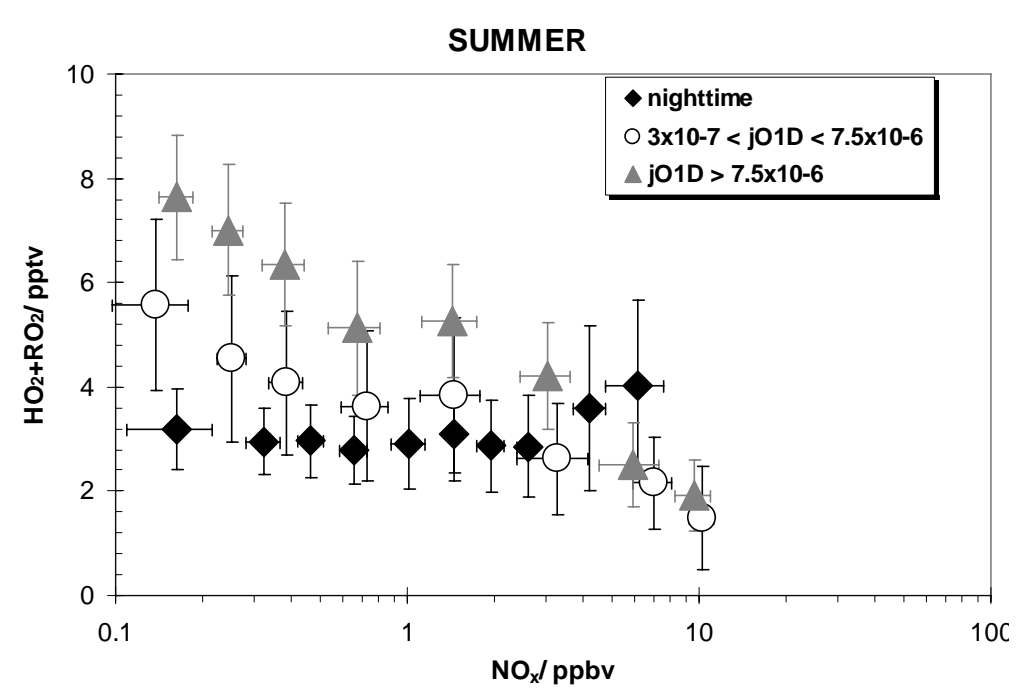

(B)

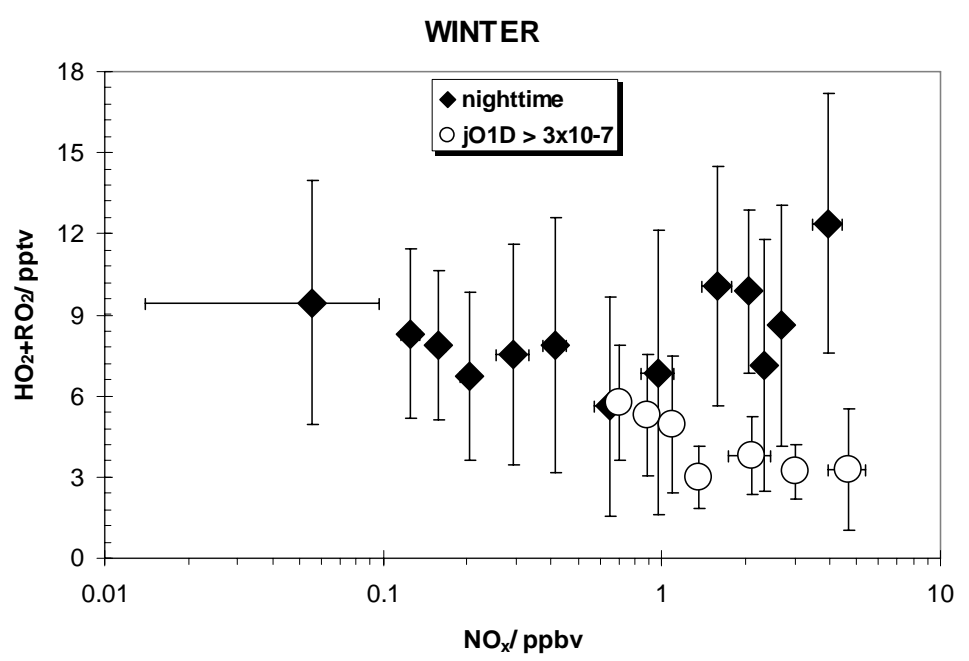

(C)

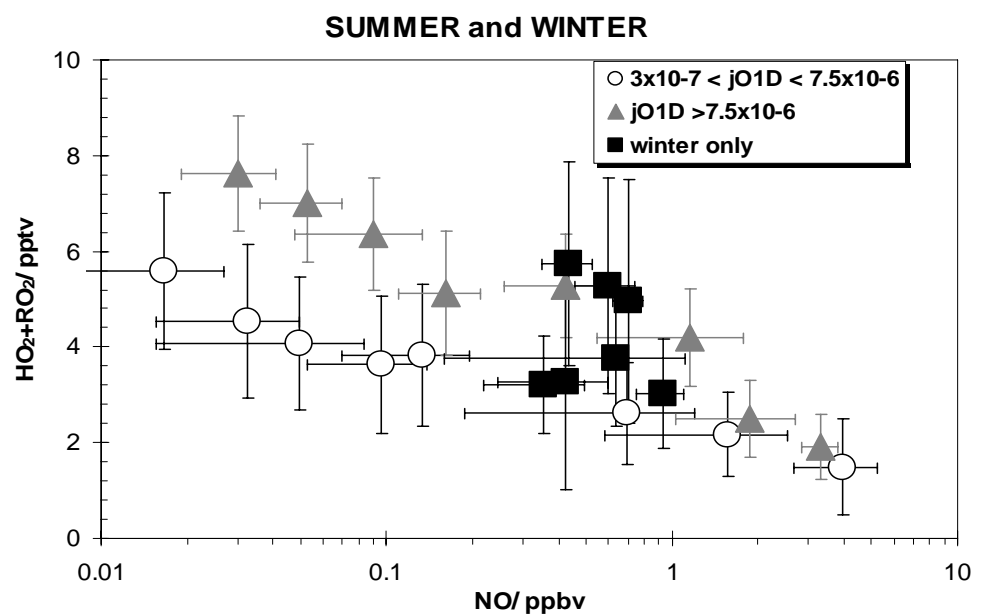

Fig. 8. (a) and (b): Hourly peroxy radical concentration vs. binned hourly $\mathrm{NO}_{\mathrm{x}}$ concentrations for daylight and nighttime conditions for summer (high and low $j\left(\mathrm{O}^{1} \mathrm{D}\right)$ and nighttime) and winter $\left(j\left(\mathrm{O}^{1} \mathrm{D}\right)>3 \times 10^{-7} \mathrm{~s}^{-1}\right.$ daytime and nighttime); (c) Hourly peroxy radical concentrations vs. binned hourly NO concentrations are also plotted for both winter and summer daylight hours. 
NO converts peroxy radicals to $\mathrm{OH}$ via Reactions (7)-(9) and at high $\mathrm{NO}_{\mathrm{x}}, \mathrm{OH}$ reacts with $\mathrm{NO}_{2}$ to form $\mathrm{HNO}_{3}$, reducing peroxy radical regeneration via $\mathrm{OH}$-oxidation of $\mathrm{CO}$ and hydrocarbons. The decrease in peroxy radicals at high $\mathrm{NO}_{x}$ seen in both seasons was predicted by Liu et al. (1980) and Logan et al. (1981). They showed that at low to intermediate $\mathrm{NO}_{\mathrm{x}}$ levels, $\mathrm{HO}_{2}$ does not change with $\mathrm{NO}_{\mathrm{x}}$ but that $\mathrm{RO}_{\mathrm{x}}$ could increase with increasing $\mathrm{NO}_{\mathrm{x}}$ because its precursors may correlate with $\mathrm{NO}_{\mathrm{x}}$. This could correspond to $\mathrm{NO}_{\mathrm{x}}$ levels where peroxy radicals show a slight increase. At high $\mathrm{NO}_{\mathrm{x}}$ levels peroxy radicals should decrease owing to removal by radical- $\mathrm{NO}_{\mathrm{x}}$ reactions.

Carpenter et al. (1998) noted a negative correlation between PSS-derived peroxy radical concentrations and $\mathrm{NO}_{\mathrm{x}}$ at Weybourne in winter 1994. Holland et al. (2003) found at the BERLIOZ campaign, outside Berlin (Germany), that for $\left[\mathrm{NO}_{\mathrm{x}}\right]>1 \mathrm{ppbv}, \mathrm{HO}_{2}$ decreased as $\mathrm{NO}_{\mathrm{x}}$ increased and that for $\left[\mathrm{NO}_{\mathrm{x}}\right]<1 \mathrm{ppbv}, \mathrm{HO}_{2}$ increased with increasing $\mathrm{NO}_{\mathrm{x}}$. During the TOPSE campaign (in N. America), Stroud et al. (2004) found that peroxy radical production appears to decrease with $\mathrm{NO}_{\mathrm{x}}$ in the winter (when radicals are lower) and increase in the spring (when peroxy radicals are higher). However, Cantrell et al. (2003) found that these high peroxy radical levels were from high radical-producing reactions (mainly by photolysis) and not directly because of $\mathrm{NO}_{\mathrm{x}}$.

\subsection{Night-time chemistry}

During the night, in Fig. 8, at $\left[\mathrm{NO}_{\mathrm{x}}\right]>1$ ppbv the peroxy radical levels during both the winter and the summer are higher than at low $\left[\mathrm{NO}_{\mathrm{x}}\right]$. This may be explained by $\mathrm{NO}_{3}$ radical reactions being one of the major formation routes for peroxy radicals (Salisbury et al., 2001). The gradient of the increase in night-time peroxy radical levels from low to high $\mathrm{NO}_{\mathrm{x}}$ is greater in winter than in summer (1.64 for winter and 0.21 for summer for values of $\mathrm{NO}_{\mathrm{x}}>1 \mathrm{ppbv}$ ). Table 3 shows that the average night-time peroxy radical concentrations in summer do not seem to vary with $\mathrm{NO}_{\mathrm{x}}$ below 1 ppbv. In winter, peroxy radical concentrations are much higher and there is a greater variation during the night than the day.

Figure 9 shows the hourly average peroxy radical concentrations during the night in winter and summer. The highest night-time concentration in summer was at $19.00(\approx 12 \mathrm{pptv})$, and throughout the night the concentrations decrease. For the last three nights of the summer campaign (where $\mathrm{NO}_{\mathrm{x}}$ levels were higher), this decrease is even more apparent. Peroxy radical concentrations in winter also show a decreasing trend throughout the night. The percentage decrease throughout the night is greater in the winter $(50 \%$, ca. 4 pptv) than in the summer $(30 \%$, ca. 2 pptv). This decrease in peroxy radicals throughout the night is likely due to a reduced $\mathrm{NO}_{3}$ source strength as the night progresses, which is consistent with lower $\mathrm{NO}_{3}$ concentrations after 22:00 (Salisbury et al, 2001). The same form of behaviour was recently noted in the BERLIOZ campaign by Geyer et al. (2003), where the measured $\mathrm{NO}_{3}$ was shown to influence the night-time peroxy radical mixing ratios. Maximum $\mathrm{NO}_{3}$ and peroxy radical concentrations were between 19:00 and 22:00. Both then proceeded to decrease throughout the rest of the night. Bey et al. (2001) found, in an urban model, an evening peroxy radical peak at about 19:00, whereas in a rural environment, this peak was much lower and the marked decrease in peroxy radicals into the night was no longer seen.

The night-time $\mathrm{NO}_{\mathrm{x}}$ peroxy radical trends in Fig. 8 suggest that $\mathrm{NO}_{3}$ has a stronger influence on peroxy radical formation in winter than summer. This type of analysis, on hourly data rather than campaign-averaged data, shows a better $\mathrm{NO}_{3}$ correlation because it is often a sudden $\mathrm{NO}_{\mathrm{x}}$ increase that causes a rise in peroxy radicals. Without supporting data it is difficult to confirm which other peroxy radical forming mechanisms (like ozone-alkene reactions) are important (see Salisbury et al., 2001).

\subsection{Photochemical ozone production}

The ozone tendency or net photochemical in-situ production rate of ozone $\left(\mathrm{N}\left(\mathrm{O}_{3}\right)\right)$ is a measure of the ozone productivity of an air mass and neglects transport and deposition processes (see for example Monks et al., 2000). $\mathrm{N}\left(\mathrm{O}_{3}\right)$ is made up of a production term, $\mathrm{P}\left(\mathrm{O}_{3}\right)$ minus the loss term, $\mathrm{L}\left(\mathrm{O}_{3}\right)$ :

$$
\begin{gathered}
\mathrm{N}\left(\mathrm{O}_{3}\right)=k_{p}[\mathrm{NO}]\left[\mathrm{HO}_{2}+\Sigma \mathrm{RO}_{2}\right]- \\
\left\{f . j\left(\mathrm{O}^{1} \mathrm{D}\right)+k_{15}[\mathrm{OH}]+k_{12}\left[\mathrm{HO}_{2}\right]\right\}\left[\mathrm{O}_{3}\right]
\end{gathered}
$$

Where $k_{p}$ is a combined rate coefficient for the oxidation of $\mathrm{NO}$ to $\mathrm{NO}_{2}$ by all peroxy radicals and f. $j\left(\mathrm{O}^{1} \mathrm{D}\right)\left[\mathrm{O}_{3}\right]$ represents the fraction of ozone photolysed to yield $\mathrm{O}\left({ }^{1} \mathrm{D}\right)$ atoms and then $\mathrm{OH}$ (with $\mathrm{f}$ being the proportion of $\mathrm{O}\left({ }^{1} \mathrm{D}\right)$ atoms which react with $\mathrm{H}_{2} \mathrm{O}$ to give $\mathrm{OH}$ rather than being collisionally deactivated). The rate constants $k_{15}$ and $k_{12}$ are from the ozone loss reactions:

$\mathrm{OH}+\mathrm{O}_{3} \rightarrow \mathrm{HO}_{2}+\mathrm{O}_{2}$

$\mathrm{HO}_{2}+\mathrm{O}_{3} \rightarrow \mathrm{OH}+2 \mathrm{O}_{2}$

The assumptions inherent in these forms of calculations are detailed in Salisbury et al. (2002). Ozone production, destruction and net production values were calculated for each daylight hour of both campaigns and averaged. Figure 10 and Table 4 shows the net summer and winter hourly averaged ozone formation, with the loss and production terms shown separately. The most obvious difference between winter and summer is the much higher ozone loss occurring in summer. In summer, the hourly ozone loss is mostly lower than ozone production but on some days with low NO concentrations, and subsequently lower ozone production rates, overall ozone destruction (negative $\mathrm{N}\left(\mathrm{O}_{3}\right)$ ) occurs. The averaging of all days in Fig. 10 hides these few hours of ozone destruction. In winter, $\mathrm{L}\left(\mathrm{O}_{3}\right)$ is very low (see Table 4) and $\mathrm{N}\left(\mathrm{O}_{3}\right)$ is controlled mainly by $\mathrm{P}\left(\mathrm{O}_{3}\right)$. 
(A) SUMMER

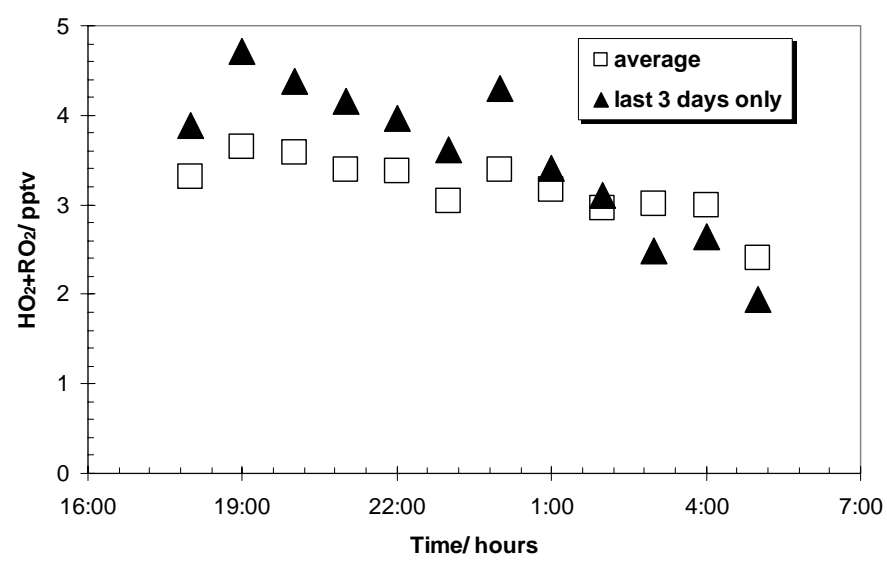

(B)

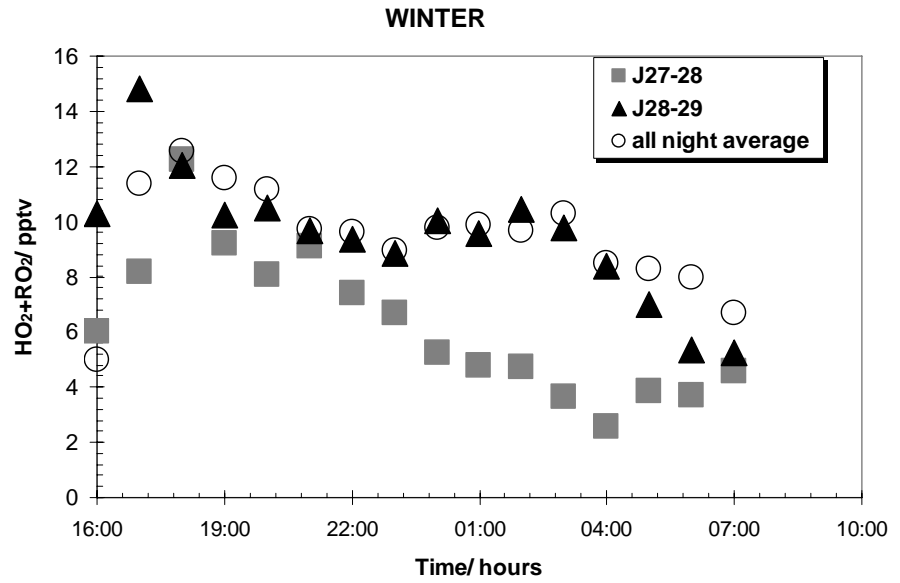

Fig. 9. Average night time $\mathrm{HO}_{2}+\Sigma \mathrm{RO}_{2}$ concentrations for (a) summer (all nights and just last 3 nights, where [NO ] was significantly higher) and (b) winter (all nights and the only two complete nights). Time throughout the night is shown in GMT.

Table 4. A comparison of the overall winter and summer ozone production and loss terms (08:00-16:00 averages).

\begin{tabular}{lll}
\hline & Summer $\backslash p p b h^{-1}$ & Winter $\backslash p p b h^{-1}$ \\
\hline $\mathrm{P}\left(\mathrm{O}_{3}\right)$ & 1.68 & 1.13 \\
$\mathrm{~L}\left(\mathrm{O}_{3}\right)$ & 0.17 & 0.02 \\
$\mathrm{~N}\left(\mathrm{O}_{3}\right)$ & 1.51 & 1.11 \\
\hline
\end{tabular}

The flat shape of the $\mathrm{N}\left(\mathrm{O}_{3}\right)$ average diurnal cycle during the middle of the day (at its maximum) in summer is not a good representation of the individual day's variability. Large variations of $\mathrm{P}\left(\mathrm{O}_{3}\right)$ from day to day in the summer are observed owing to $\mathrm{NO}$ variability and spikes (mainly in the morning). In Fig. 10, the only time that ozone production was higher in summer than in winter was in the early morning, owing to the elevated NO experienced in summer at this time of day. The NO concentration appears to be more of a determining factor than the peroxy radical concentration on $\mathrm{N}\left(\mathrm{O}_{3}\right)$ in winter, than it does in the summer.

The apparent $\mathrm{N}\left(\mathrm{O}_{3}\right)$ campaign averages are higher in summer compared to winter, but particularly at midday during the winter there appears to be a much higher potential to form ozone. An important assumption of the in-situ ozone productivity calculations is that of a steady-state.

\section{7 $\mathrm{NO}-\mathrm{NO}_{2}-\mathrm{O}_{3}$ photostationary state}

Averaging ozone productivity over each campaign gives the appearance that there is a significant net ozone production in both winter and summer. The differences between the NO and $\mathrm{NO}_{\mathrm{x}}$ dependence of the peroxy radicals in Fig. 8 is suggestive of $\mathrm{NO}$ and $\mathrm{NO}_{2}$ not being in a photostationary state (PSS) equilibrium in winter as the $\mathrm{NO} / \mathrm{NO}_{2}$ ratio is highly variable. In-situ ozone production relies on the system being in steady state (inter alia Eq. 16).

Figure 11 shows the $\mathrm{NO} / \mathrm{NO}_{2}$ ratio in winter and summer. 

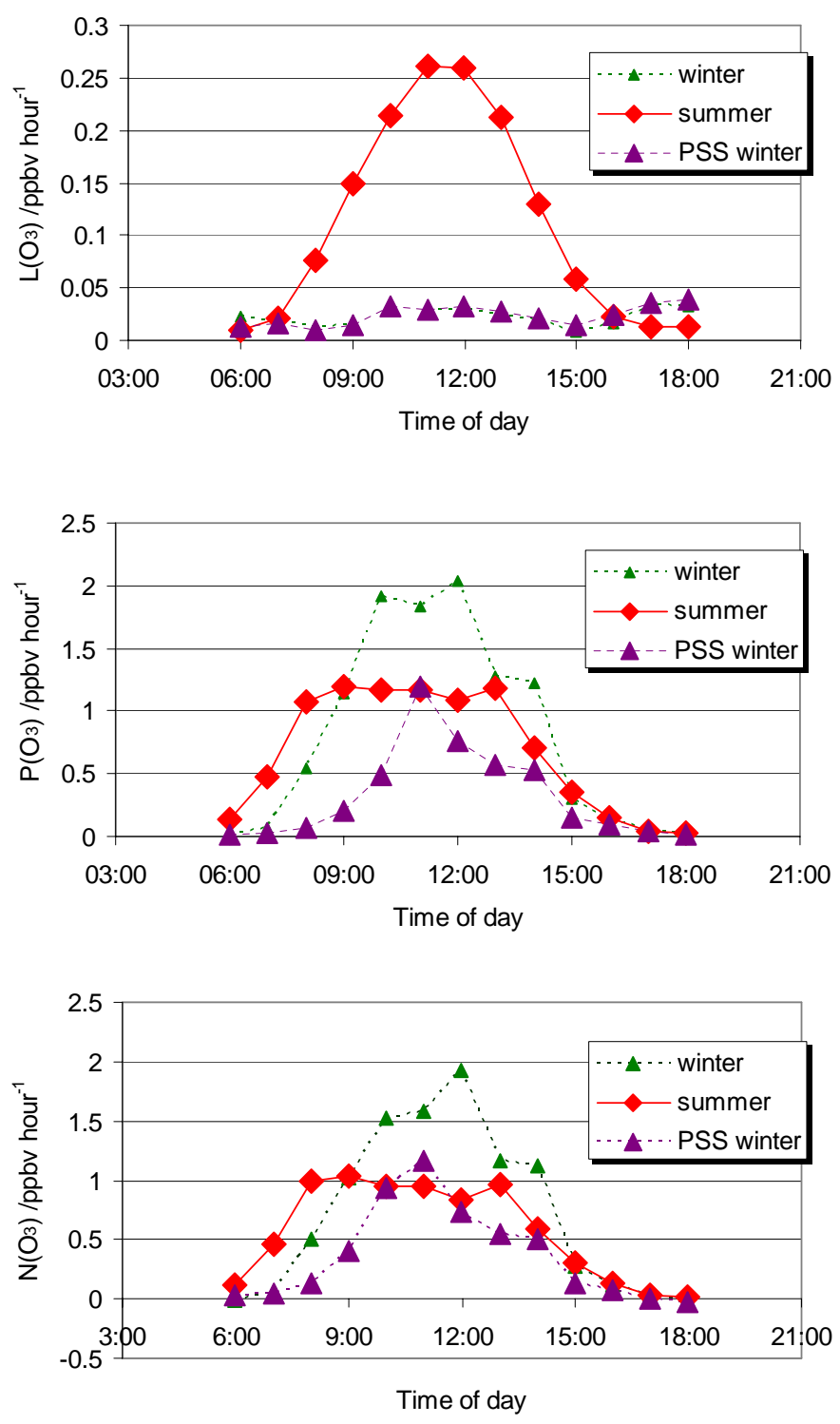

Fig. 10. Average daylight ozone tendencies (production minus destruction per hour, $\mathrm{N}\left(\mathrm{O}_{3}\right)$ ) for the summer and winter campaigns (integrated hourly averages) and ozone production $\left(\mathrm{P}\left(\mathrm{O}_{3}\right)\right)$ and destruction terms $\left(\mathrm{L}\left(\mathrm{O}_{3}\right)\right)$. For winter both PSS days and all data are shown.

In winter, three days (27, 29 January and 3 February) showed $\mathrm{NO} / \mathrm{NO}_{\mathrm{x}}$ ratios above 0.5 , having $\mathrm{NO}$ concentrations higher than $\mathrm{NO}_{2}$ concentrations. The lower light levels of winter and other factors (e.g. emissions, PBL height) may contribute to the inability of the system to obtain photostationary equilibrium of $\mathrm{NO}_{\mathrm{x}}$. The average [NO] in summer is $0.04 \mathrm{ppbv}$ and in winter, $0.14 \mathrm{ppbv}$, while $\left[\mathrm{NO}_{2}\right]$ is $0.34 \mathrm{ppbv}$ in summer and $1.58 \mathrm{ppbv}$ in winter. [NO] is on average ten times as high in summer as winter, and yet $\left[\mathrm{NO}_{2}\right]$ is only slightly higher in the summer. The time required for photostationary state to reach equilibrium after perturbation (Yang et al., 2004) by either $j\left(\mathrm{NO}_{2}\right)$ or $[\mathrm{NO}] /\left[\mathrm{NO}_{2}\right]$ is given by

$\tau_{\mathrm{PSS}}=\frac{-\ln 0.05}{j\left[\mathrm{NO}_{2}\right]+k_{14}\left[\mathrm{O}_{3}\right]}$
Here $\tau_{\text {PSS }}$ is defined as the time interval required for NO to complete $95 \%$ of the readjustment. For winter the average value of $\tau_{\text {PSS }}$ is of the order of $225 \mathrm{~s}$ and $176 \mathrm{~s}$ in summer.

The average $\mathrm{NO}_{2}$ lifetime $\left(1 / j\left(\mathrm{NO}_{2}\right)\right)$ between 08:00 and 16:00 was calculated to be $5 \mathrm{~min}$ in summer and $21 \mathrm{~min}$ in winter. In summer, the lifetime does not vary significantly in the daylight hours but in winter the values vary from ca. $10 \mathrm{~min}$ around midday to ca. $40 \mathrm{~min}$ between 08:00 and 15:00. Thus, the ratio $\mathrm{NO} / \mathrm{NO}_{2}$ is not as stable in winter as a photostationary state takes longer to be reached. Carpenter et al. (1998) found $\mathrm{NO}_{2}$ lifetimes to be between 5 and $20 \mathrm{~min}$ (between 09:30 and 14:30) at Weybourne in winter 1993.

PSS deviations from $\mathrm{NO}-\mathrm{NO}_{2}$ (Ridley et al., 1992) are a method of testing whether a system is in photostationary 

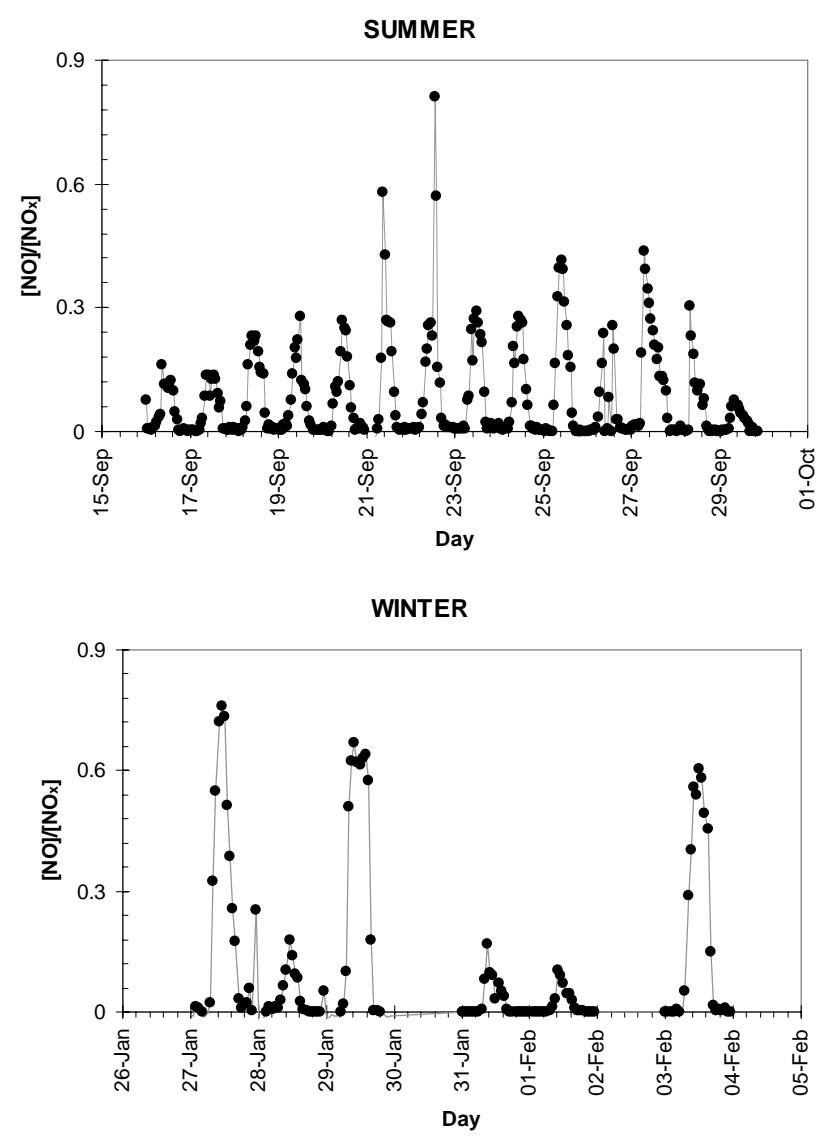

Fig. 11. Hourly $\mathrm{NO}: \mathrm{NO}_{\mathrm{x}}$ ratios during summer and winter. The winter data shows days in PSS and not (see text).

state. Deviations from PSS can be expressed according to deviations from $\phi$

$\phi=\frac{j\left(\mathrm{NO}_{2}\right)\left[\mathrm{NO}_{2}\right]}{k_{14}[\mathrm{NO}]\left[\mathrm{O}_{3}\right]}$

During the summer, $\phi$ values were closer to 1 than in winter (daily averages between 0.86 and 1.12 for 17 to 25 September, with standard deviations of 0.08 to 0.39 ) but with the 16 September and the last 4 days (26 to 29 September) showing a tendency towards high $\phi$ ratios. These $\phi( \pm$ their $1 \sigma$ standard deviations) were $1.43 \pm 0.6,6.84 \pm 13.6,1.20 \pm 0.3$, $1.55 \pm 0.5$ and $6.66 \pm 1.21$ respectively.

Winter daily averaged $\phi$ values between 08:00 and 17:00 were calculated to be $1.35 \pm 0.5,1.60 \pm 1.2,1.04 \pm 0.1$ for 28 , 31 January and 1 February, and $0.06 \pm 0.01$ and $0.08 \pm 0.01$ for 29 January and 3 February. A value of $\phi$ equal to $1 \mathrm{im}$ plies a photostationary state has been established, but large deviations from this (as on 29 January and 3 February) imply photostationary state has not been reached. The 28 and 31 January had a value of $\phi>1$, similar to that seen in the summer. Some care must be exercised with this analysis as demonstrated by Mannschreck et al. (2004).

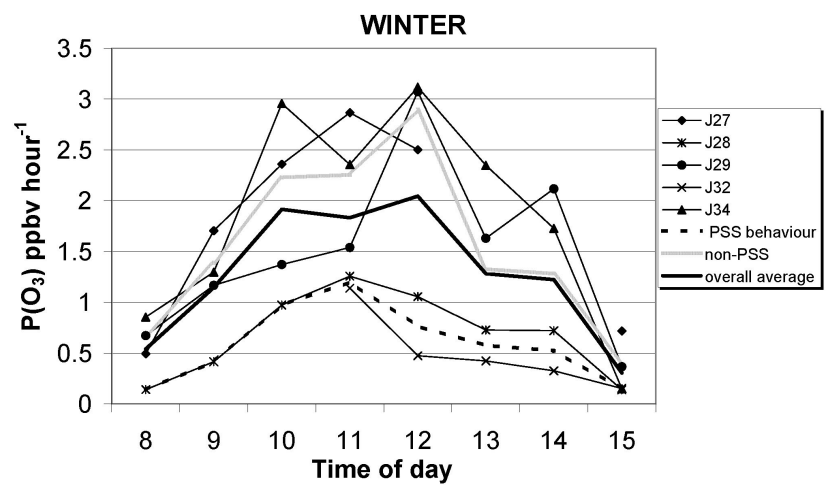

Fig. 12. $\mathrm{P}\left(\mathrm{O}_{3}\right)$ calculations for a series of the winter campaign days. Three average lines are superimposed that represent (I) the overall average, (II) the non-PSS daily averages and (III) the PSS daily averages.

Deviations of $\phi$ from 1 and $\mathrm{NO} / \mathrm{NO}_{2}$ ratios, create a clear division between the 27, 29 January and 3 February, which display non-PSS characteristics and 28 January and 1 February, which show good PSS behaviour. The average $\left[\mathrm{NO}_{\mathrm{x}}\right]$ for the PSS sector was $2.9 \mathrm{ppbv}$ while the non-PSS sector was $0.8 \mathrm{ppbv}$. $\mathrm{NO} / \mathrm{NO}_{2}$ ratios were $0.33 \pm 0.3$ for all the winter data, $0.08 \pm 0.05$ for the PSS sector and $0.50 \pm 0.2$ for the non-PSS sector.

Figure 12 shows the $\mathrm{P}\left(\mathrm{O}_{3}\right)$ diurnal cycle for each winter day and with the sorted averages according to ability to obtain PSS. Owing to the small amount of data, this can only illustrate that there can be large discrepancies in PSS behaviour, leading to a resultant ozone production that could be highly exaggerated. When comparing winter and summer conditions, it becomes clear that a PSS test is essential before modelling the net ozone production.

In agreement with a number of other campaigns (Salisbury et al., 2002; Volz-Thomas et al., 2003; Yang et al., 2004) PSS calculated values of $\mathrm{N}\left(\mathrm{O}_{3}\right)$ overestimate those calculated using the measured radical concentrations. Volz-Thomas et al. 2003 ascribe this general failing to an unidentified process which must exist in the atmosphere that converts NO to $\mathrm{NO}_{2}$ without leading to a net production of ozone.

\subsection{Ozone production vs. $\left[\mathrm{NO}_{\mathrm{x}}\right]$}

The calculated hourly-averaged net ozone production, $\mathrm{N}\left(\mathrm{O}_{3}\right)$ for the summer and winter campaigns are plotted against [NO] in Fig. 13a along with air mass sector division averages. There appears to be a general increase in net ozone production as NO concentration increases. For $[\mathrm{NO}]>2 \mathrm{ppbv}$ $\mathrm{N}\left(\mathrm{O}_{3}\right)$ reaches its highest values but no longer appears to increase with increasing NO. The ozone production, $\mathrm{P}\left(\mathrm{O}_{3}\right)$ vs. NO concentration graph in Fig. 13b appears very similar to the previous graph because high $\mathrm{P}\left(\mathrm{O}_{3}\right)$ values are hardly reduced when the $\mathrm{L}\left(\mathrm{O}_{3}\right)$ is subtracted to calculate $\mathrm{N}\left(\mathrm{O}_{3}\right)$. 
The lower $\mathrm{P}\left(\mathrm{O}_{3}\right)$ and $\mathrm{N}\left(\mathrm{O}_{3}\right)$ values are more different to each other as ozone loss affects $\mathrm{N}\left(\mathrm{O}_{3}\right)$ much more but due to the density of values, it is hard to see any differences between Fis. 13a and $b$.

The $\mathrm{N}\left(\mathrm{O}_{3}\right)$ hourly averages cover a range of hourly $\mathrm{NO}$ concentrations between 10 and 4500 pptv. The winter conditions lead only to positive $\mathrm{N}\left(\mathrm{O}_{3}\right)$ (ozone production), whereas, during the summer, the low NO concentrations on some days along with greater ozone destruction, lead to net negative ozone tendencies (for short periods).

At $[\mathrm{NO}]>0.1 \mathrm{pptv}, \mathrm{P}\left(\mathrm{O}_{3}\right)$ is higher in winter than in summer but at higher NO there is little difference in the resulting $\mathrm{P}\left(\mathrm{O}_{3}\right)$ between the seasons. Winter data have a more scattered $\mathrm{P}\left(\mathrm{O}_{3}\right)$-NO trend than in summer. The winter average, PSS days and non-PSS days all show a higher $\mathrm{N}\left(\mathrm{O}_{3}\right)$ than those taken in the summer air-mass-sectors of a similar NO concentration.

Mihelcic et al. (2003), at the BERLIOZ campaign near Berlin, observed an increase in ozone production, $\mathrm{P}\left(\mathrm{O}_{3}\right)$ up until ca. $0.3 \mathrm{ppbv} \mathrm{NO}$ and then a gradual decrease with increasing NO. Similarly, measurements by the same group at Schaunisland in the Black forest, as well as measurements by Zenker et al. (1998) in Tenerife at the OCTA (Oxidising Capacity of the Tropospheric Atmosphere) campaign, found an increase in ozone production up to similar NO values of 0.25 to $0.3 \mathrm{ppbv}$ and a decrease at higher NO. The Weybourne 2002 data showed no such decrease in ozone production.

The average $\operatorname{dln} \mathrm{P}\left(\mathrm{O}_{3}\right) / \mathrm{d} \ln \left[\mathrm{NO}_{x}\right]$ (with standard deviations in brackets) for summer and winter were 1.04 (6.70) and 2.00 (21.3). These values imply that $\mathrm{NO}_{\mathrm{x}}$ affects $\mathrm{P}\left(\mathrm{O}_{3}\right)$ in an essentially linear fashion in summer, and that the same $\mathrm{NO}_{\mathrm{x}}$ leads to twice as efficient in winter as it would in summer (see also Fleming et al., 2006). Hourly averaged $\mathrm{d} \operatorname{lnL}\left(\mathrm{O}_{3}\right) / \mathrm{d} \ln \left[\mathrm{NO}_{\mathrm{x}}\right]$ in summer and winter were 0.08 (6.38) and 1.49 (14.2). $\mathrm{NO}_{\mathrm{x}}$ has an indirect effect on $\mathrm{L}\left(\mathrm{O}_{3}\right)$ as it affects the $\mathrm{O}_{3}$ reactions with $\mathrm{OH}$ and $\mathrm{HO}_{2}$ and not the photolysis term. $\mathrm{L}\left(\mathrm{O}_{3}\right)$ is much less affected by $\mathrm{NO}_{\mathrm{x}}$ in summer, as photolysis is the major loss route but $\mathrm{NO}_{\mathrm{x}}$ has a significant effect on $\mathrm{L}\left(\mathrm{O}_{3}\right)$ in winter through the reactions of ozone with $\mathrm{OH}$ and $\mathrm{HO}_{2}$, whose concentrations are all affected by $\mathrm{NO}_{\mathrm{x}}$.

Many prior studies have noted an increase in net ozone formation with increasing $\mathrm{NO}_{\mathrm{x}}\left(\mathrm{NO}+\mathrm{NO}_{2}\right)$, such as during the TOPSE flights over North America in the free troposphere where Stroud et al. (2004) calculated $\operatorname{dn} \ln \left(\mathrm{O}_{3}\right) / \mathrm{d} \ln \left[\mathrm{NO}_{\mathrm{x}}\right]$ to be between 0.86 and 1.02 and $\operatorname{dln} L\left(\mathrm{O}_{3}\right) / \mathrm{d} \ln \left[\mathrm{NO}_{\mathrm{x}}\right]$ to be only 0.2. It should be noted, however, that the $\mathrm{NO}_{\mathrm{x}}$ concentrations were mostly between 10 and 500 pptv whereas $\mathrm{NO}_{\mathrm{x}}$ at Weybourne was generally between 500 and 6000 pptv. Daily net ozone production values for winter and summer are shown in Fig. 14. During the summer, the daily $\mathrm{N}\left(\mathrm{O}_{3}\right)$ was always positive except on 16 September $(\mathrm{J} 259)$, where $\mathrm{N}\left(\mathrm{O}_{3}\right)$ was negative at $-0.03 \mathrm{ppbv} \mathrm{h}^{-1}$. The daily $\mathrm{N}\left(\mathrm{O}_{3}\right)$ ranged from -0.3 to $2.2 \mathrm{ppbv} \mathrm{h}^{-1}$ over the course of the day. In winter, the daily $\mathrm{N}\left(\mathrm{O}_{3}\right)$ was always positive, with ozone production of $0.5,0.6$ and $1.2 \mathrm{ppbv} \mathrm{h}^{-1}$ for the PSS days and 1.5 to $1.8 \mathrm{ppbv} \mathrm{h}^{-1}$ for
A)

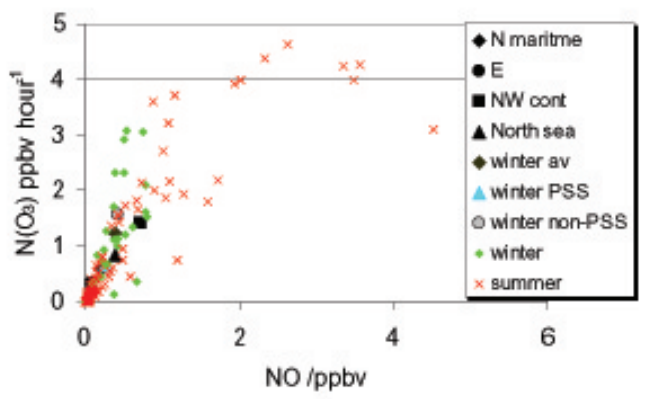

B)

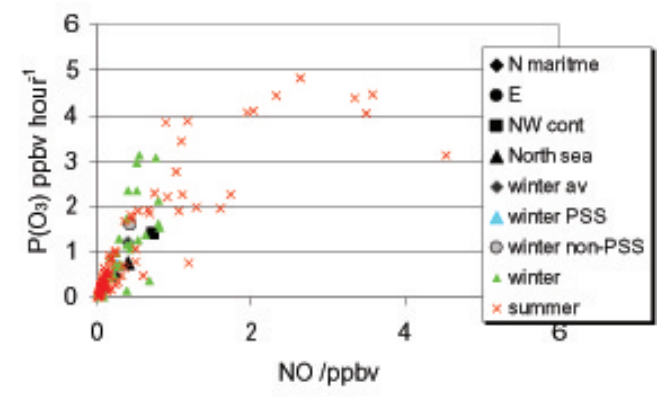

C)

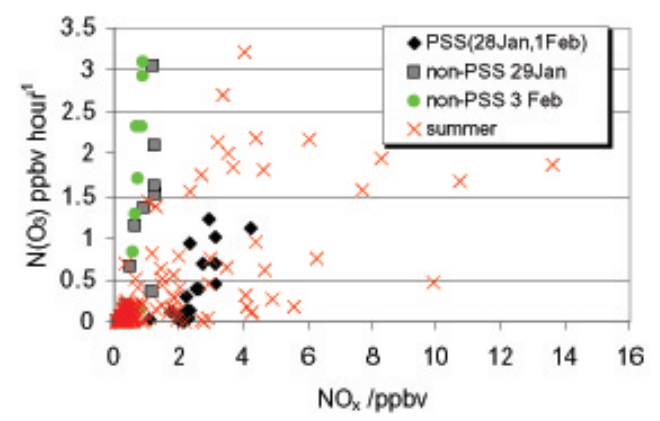

Fig. 13. (a) Calculated ozone tendencies vs. [NO] for summer and winter campaigns for hourly values; (b) Ozone production vs. NO for summer and winter hourly values; (c) $\mathrm{N}\left(\mathrm{O}_{3}\right)$ vs. $\mathrm{NO}_{\mathrm{x}}$ with winter separated into PSS days (J28,J32) and non-PSS (J29,J34).

the non-PSS days. The NO concentration needed to produce net ozone production (known as the compensation point, see Monks, 2005) for Weybourne during summer was calculated to be 57 pptv [NO]. This explains why the majority of hours show positive net ozone production, since the NO concentration was usually above the $57 \mathrm{pptv}$ threshold point during the daylight hours There was not enough data to calculate an equivalent value for winter. Both Zanis et al. (2003) and Stroud et al. (2004) have noted a seasonal variation of the compensation point, typically a smaller [NO] being required in winter vs. summer for net ozone production. For example, in the Arctic in the compensation point was $10 \mathrm{pptv}$ in winter compared to $30 \mathrm{pptv}$ in summer (Stroud et al., 2004), leading to significant net positive ozone production in winter. 


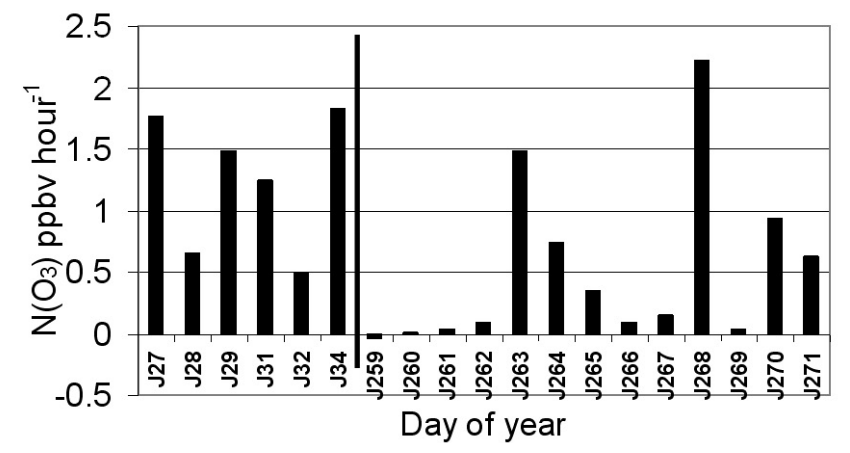

Fig. 14. Winter and summer daily $\mathrm{N}\left(\mathrm{O}_{3}\right)$ values (calculated from averaging hourly averages (06:00-19:00 in summer and 08:0016:00 in winter)). Julian day J27 is 27 January and J259 is 16 September 2002.

\section{Conclusions}

A seasonal comparison of peroxy radical data obtained at the Weybourne Atmospheric Observatory on the North Norfolk coast of the UK has shown that the typical peroxy radical diurnal cycle is very different in winter and summer.

During the summer the maximum peroxy radical concentrations were at midday, when ozone photolysis is highest. Exceptions to this were when $\mathrm{NO}_{\mathrm{x}}$ concentrations were high and daytime peroxy radical levels were suppressed. In the winter, daylight hours saw very low peroxy radical concentrations as the solar intensity was not enough to drive substantial photochemical formation. However, during the night, large concentrations of peroxy radicals were formed in winter, making night-time levels much higher than daylight levels and even up to twice as high as the maximum summer daytime concentrations. Night-time peroxy radical formation leads to much higher average peroxy radical concentrations in winter than summer.

In the daytime, peroxy radicals show a distinct general trend, with increasing $\mathrm{NO}_{\mathrm{x}}$ in summer and winter, decreasing with increasing $\mathrm{NO}_{\mathrm{x}}$. In summer, at $\mathrm{NO}_{\mathrm{x}}$ concentrations of just over $1 \mathrm{ppbv}$, the peroxy radical concentration appears to increase slightly before continuing to decrease at higher $\mathrm{NO}_{\mathrm{x}}$ concentrations. This behaviour may indicate the system is no longer $\mathrm{NO}_{\mathrm{x}}$-limited. In winter, the range of $\mathrm{NO}_{\mathrm{x}}$ is between 0.7 and $1.4 \mathrm{ppbv}$, and a decrease in peroxy radical concentrations is seen with increasing $\mathrm{NO}_{\mathrm{x}}$.

During the night, in both winter and summer, above $1 \mathrm{ppbv}$ $\mathrm{NO}_{\mathrm{x}}$, peroxy radical concentrations increase. This has been attributed to peroxy radical formation from $\mathrm{NO}_{3}$ chemistry, with a sharper increase in peroxy radical concentrations at high $\mathrm{NO}_{\mathrm{x}}$ in winter. Also, the peroxy radical concentration tended to decrease throughout the night in both seasons with the maximum concentration at the start of the night.

Winter and summer average diurnal cycles of net ozone productivity show that there is apparently similar ozone pro- duction in summer and winter. The magnitude is driven by two factors, the first is the larger range of air-mass variability summer vs. winter. The second is the substantially smaller photochemical ozone loss term in winter vs. summer coupled to the apparent ability to produce ozone in winter under low radical high $[\mathrm{NO}]$ conditions. Closer inspection of the winter ozone production terms suggest that on many occasions photostationary state is not achieved leading to a potential to overestimate ozone production. Photostationary state calculations found the $\mathrm{NO}_{2}$ lifetimes in summer and winter to be 5 and $21 \mathrm{~min}$ respectively, showing the $\mathrm{NO} / \mathrm{NO}_{2}$ ratio to be less stable in winter. Trends of net ozone production, $\mathrm{N}\left(\mathrm{O}_{3}\right)$ against $\mathrm{NO}$ concentrations show that as $\mathrm{NO}$ increases, a similar increase in $\mathrm{N}\left(\mathrm{O}_{3}\right)$ is observed. Average $\mathrm{d} \ln \mathrm{P}\left(\mathrm{O}_{3}\right) / \mathrm{d} \ln \left[\mathrm{NO}_{\mathrm{x}}\right]$ for summer and winter have been determined to be 1.04 and 2.00. In general, similar [NO] concentrations lead to higher net ozone formation in winter than summer.

In summary, the data shows an active peroxy radical chemistry during the night-time during the winter season than would be expected, though the concomitant daytime levels where low, they were still large enough to drive significant net ozone production. The net effect of this with respect to production of ozone in winter is unclear owing to the breakdown in the photostationary state but could lead to levels of ozone production in winter as a result of the correspondingly lower photochemical ozone destruction rates. A further study with greater coverage would statistically prove the differences in ozone formation between the seasons.

Acknowledgements. We are grateful to the British Atmospheric Data Centre for providing access to calculated trajectories using data from the European Centre for Medium Range Weather Forecasts. The authors are also grateful to G. Phillips for logistical support. The work has been funded by the EU through the INSPECTRO project. CER is grateful to NERC-NCAS-DIAC for support. SAP is grateful to the Leverhulme trust for an Emeritus Fellowship. Weybourne Atmospheric observatory is supported in part by NERC-NCAS-UFAM.

Edited by: J. Williams

\section{References}

Allan, B. J., Carslaw, N., Coe, H. Burgess, R. A., and Plane, J. M. C.: Observations of the nitrate radical in the marine boundary layer, J. Atmos. Chem., 33, 129-154, 1999.

Atkinson, R.: Atmospheric chemistry of VOCs and $\mathrm{NO}_{\mathrm{x}}$, Atmos. Environ., 34, 2063-2101, 2000.

Bey, I., Aumont, B., and Toupance, G.: A modelling study of the nighttime radical chemistry in the lower continental troposphere 1. Development of a detailed chemical mechanism including nighttime chemistry, J. Geophys. Res., 106, 9959-9990, 2001 . 
Brönnimann, S.: Early spring ozone episodes: Occurrence and case study, Phys. Chem. Earth Part C, 24, 531-536, 1999

Brough, N., Reeves, C. E., Penkett, S. A., Stewart, D. J., Dewey, K., Kent, J., Barjat, H., Monks, P. S., Ziereis, H., Stock, P., Huntrieser, H., and Schlager, H.: Intercomparisons of aircraft instruments on board the C-130 and Falcon 20 over southern Germany during EXPORT 2000, Atmos. Chem. Phys., 5, $2127-$ 2138, 2003, http://www.atmos-chem-phys.net/5/2127/2003/.

Burkert, J., Andrés-Hernández, M. D., Reichert, L., Meyer-Arnek, J., Doddridge, B., Dickerson, R. R., Mühle, J., Zahn, A., Carsey, T., and Burrows, J. P.: Trace gas and radical diurnal behaviour in the marine boundary layer during INDOEX 1999, J. Geophys. Res, 108, 8000, doi:10.1029/2002JD002790, 2003.

Cantrell, C. A., Stedman, D. H., and Wendel, G. J.,: Measurement of atmospheric peroxy radicals by chemical amplification, Anal. Chem., 56, 1496-1502, 1984.

Cantrell, C. A., Shetter, R. E., and Calvert, J. G.: Dual-inlet Chemical amplifier for atmospheric peroxy radical measurements, Anal. Chem., 58, 4194-4199, 1996.

Cantrell, C. A., Edwards, G. D., Stephens, S., Mauldin, L., Kosciuch, E., Zondlo, M., and Eisele, F.: Peroxy radical observations using chemical ionisation mass spectrometrey during TOPSE, J. Geophys. Res., 108, 8371, doi:10.1029/2002JD002715, 2003.

Cardenas, L. M., Austin, J. F., Burgess, R. A., Clemitshaw, K. C., Dorling, S., Penkett, S. A., and Harrison, R. M.: Correlation between $\mathrm{CO}, \mathrm{NO}_{\mathrm{y}}, \mathrm{O}_{3}$ and non-methane hydrocarbons and their relationships with meteorology during winter 1993 on the North Norfolk coast, UK, Atmos. Environ., 32, 3339-3351, 1998.

Carpenter, L. J., Clemitshaw K. C., Burgess R. A., Penkett S. A., Cape J. N., and McFadyen G. C.: Investigation and evaluation of the $\mathrm{NO}_{\mathrm{x}} / \mathrm{O}_{3}$ photochemical steady state, Atmos. Environ., 32, 3353-3365, 1998.

Carslaw, N., Carpenter, L. J., Plane, J. M. C.., Allan, B. J., Burgess, R. A. Clemitshaw, K. C., Coe, H., and Penkett, S. A.: Simultaneous observations of nitrate and peroxy radicals in the marine boundary layer, 1 . Model construction and comparison with field measurements, J. Geophys. Res., 102, 18 917-18 933, 1997.

Clemitshaw, K. C. and Penkett, S. A.: TOR station number 7: The Weybourne atmospheric observatory, in: The TOR network. A description of TOR Measurement Stations, edited by: Cvitas, T. and Kley, D., EUROTRAC International Scientific Secretariat Garmisch Partenkirchen, 59-63, 1994.

Clemitshaw, K. C., Carpenter, L. J., Penkett, S. A., and Jenkin, M. E.: A calibrated peroxy radical chemical amplifier (PERCA) for ground-based measurements in the troposphere, J. Geophys. Res., 102, 25 405-25 416, 1997.

Derwent, R. G., Simmonds, P. G., Seuring, S., and Dimmer, C: Observation and interpretation of the seasonal cycles in the surface concentrations of ozone and carbon monoxide at Mace Head, Ireland from 1990 to 1994, Atmos. Env., 32, 145-157, 1998.

Edwards, G. D. and Monks, P. S.: Performance of a single monochromator diode array spectrradiometer for the determination of actinic flux and atmospheric frequencies, J. Geophys. Res., 108, 8546-8558, 2003.

Fleming, Z. L., Monks, P. S., Rickard, A. R., Heard, D. E., Bloss, W. J., Seakins, P. W., Still, T. J., Sommariva, R., Pilling, M. J., Morgan, R., Green, T. J., Brough, N., Penkett, S. A., Lewis, A. C., Lee, J. D., Saiz-Lopez A., and Plane, J. M. C.: Peroxy rad- ical chemistry and the control of ozone photochemistry at Mace Head, Ireland during the summer of 2002, Atmos. Chem. Phys., 6, 2193-2214, 2006, http://www.atmos-chem-phys.net/6/2193/2006/.

Geyer, A., Bächmann, K., Hofzumahaus, A., Holland, F., Konrad, S., Klüpfel, T., Pätz, H.-W., Perner, D., Mihelcic, D., Schäfer, H.J., Volz-Thomas, A., and Platt, U.: Nighttime formation of peroxy and hydroxyl radicals during the BERLIOZ campaign: Observations and modelling studies, J. Geophys. Res., 108, 8249, doi:10.1029/2001JD000656, 2003.

Green, T. J., Brough, N., Reeves, C. E., Edwards, G. D., Monks, P. S., and Penkett, S. A.: Airborne measurements of peroxy radicals using the PERCA technique, J. Environ. Monitoring, 5, 75-83, 2003.

Green, T. J., Reeves, C. E., Fleming, Z., Brough, N., Rickard, A. R., Bandy, B. J., Monks, P. S., and Penkett, S. A.: An Improved Dual Channel PERCA Instrument for Atmospheric Measurements of Peroxy Radicals, J. Environ. Monitoring, 8, 530-536, 2006.

Heard D. E. and Pilling, M. J.: The hydroxyl radical, Chem. Rev., 103, 5163-5198, 2003.

Heard, D. E., Carpenter, L. J., Creasey D. J., Hopkins, J. R., Lee, J. D., Lewis, A. C., Pilling, M. J., Seakins, P. W., Carslaw, N., and Emmerson, K. M.; High levels of the hydroxyl radical in the winter urban troposphere, Geophys. Res. Lett., 31, L18112, doi:10.1029/2004GL020544, 2004.

Hernández, M. D. A., Burkert, J., Reichert, L., Stöbener, D., MeyerArnek, J., Burrows, J. P., Dickerson, R. R., and Doddridge, B. G.: Marine boundary layer peroxy radical chemistry during the AEROSOLS99 campaign: Measurements and analysis, J. Geophys. Res., 106, 20 833-20 846, doi:10.1029/2001JD900113, 2001.

Hofzumahaus, A., Lefer, B. L., Monks, P. S., Hall, S. R., Kylling, A., Mayer, B., Shetter, R. E., Junkerman, W., Bais, A., Calvert, J. G., Cantrell, C. A., Madronich, S., Edwards, G. D., Kraus, A., Müller, M., Bohn, B., Schmitt, R., Johnston, P., McKenzie, R., Frost, G. J., Griffioen, E., Krol, M., Martin, T., Pfister, G., Röth E.P., Ruggaber A., Swartz, W. H., Lloyd, S. A., and VanWeele, M.: Photolysis frequency of $\mathrm{O}_{3}$ to $\mathrm{O}\left({ }^{1} \mathrm{D}\right)$ : Measurements and modelling during the International Photolysis Frequency Measurement and Modelling Intercomparison (IPMMI), J. Geophys. Res., 109, D08S90, doi:10.1029/2003JD004333, 2004.

Holland, F., Hofzumahaus, A., Schäfer, J., Kraus, A., and Pätz, H.W.: Measurements of $\mathrm{OH}$ and $\mathrm{HO}_{2}$ radical concentrations and photolysis frequencies during BERLIOZ, J. Geophys. Res., 108, 8246-8267, 2003.

Klonecki, A. A. and Levy II, H.: Tropospheric chemical ozone tendencies in $\mathrm{CO}-\mathrm{CH}_{4}-\mathrm{NO}_{\mathrm{y}}-\mathrm{H}_{2} \mathrm{O}$ system: Their sensitivity to variations in environmental parameters and their application to a global chemistry transport model study, J. Geophys. Res., 102, 21 221-21 237, 1997.

Leighton, P. A.: Photochemistry of air pollution, Academic, San Diego, California, 1961.

Liu, S. C., Kley, D., McFarland, M., Mahlman, M. D., and Levy, H.: On the origin of tropospheric ozone, J. Geophys. Res., 85, 7546-7552, 1980.

Logan, J. A., Prather, M. J., Wofsy, S. C., and McElroy, M. B.: Tropospheric chemistry: A global perspective, J. Geophys. Res., 86, 7210-7254, 1981.

Mannschreck, K., Gilge, S., Plass-Dülmer, C., Fricke, W., and 
Berresheim, H.: Assessment of the applicability of $\mathrm{NO}-\mathrm{NO}_{2}-$ $\mathrm{O}_{3}$ photostationary state to long-term measurements at the Hohenpeissenberg GAW station, Germany, Atmos. Chem. Phys., 4, 1265-1277, 2004, http://www.atmos-chem-phys.net/4/1265/2004/.

Mihelcic, D., Holland, F., Hofzumahaus, A., Hoppe, L., Konrad, S., Müsgen, P., Pätz, H.-W., Schäfer, H.-J., Schmitz, T., VolzThomas, A., Bächmann, K., Schlonski, S., Platt, U., Geyer, A., Alicke, B., and Moorgat, G. K.: Peroxy radicals during BERLIOZ at Pabstthum: Measurements, radical budgets and ozone production, J. Geophys. Res., 108, 8254-8268, 2003.

Mihele, C. M. and Hastie, D. R.: The sensitivity of the amplifier to ambient water vapour, Geophys. Res. Lett., 25, 1911-1913, 1998.

Mihele, C. M., Mozurkewich, M., and Hastie, D. R.: Radical loss in a chain reaction of $\mathrm{CO}$ and NO in the presence of water: Implications for the radical amplifier and atmospheric chemistry, Int. J. Chem. Kin., 31, 145-152, 1999.

Monks, P. S., Carpenter, L. J., Penkett, S. A., Ayers, G. P., Gillett, R. W., Galbally, I. E., and Meyer, C. P.: Fundamental ozone photochemistry in the remote boundary layer: The SOAPEX experiment, measurement and theory, Atmos. Environ., 32, 3647-3664, 1998.

Monks, P. S.: A review of the observations and origins of the spring ozone maximum, Atmos. Env., 34, 3545-3561, 2000.

Monks, P. S., Holland, G. Salisbury, G. Penkett, S. A., and Ayers, G. P.: A seasonal comparison of ozone photochemistry in the remote marine boundary layer, Atmos. Env., 34, 2547-2561, 2000.

Monks, P. S.: Chapter 6: Tropospheric photochemistry, "Handbook of Atmospheric science: Principle and Application", edited by: Hewitt, C. N. and Jackson, A. V., Blackwell Publishing, Oxford, 2003.

Monks, P. S., Rickard, A. R., and Hall, S. L.: Attenuation of spectral actinic flux and photolysis frequencies at the surface through homogeneous cloud fields, J. Geophys. Res., 109, D17206, doi:10.1029/2003JD004076, 2004.

Monks, P. S.: Gas-phase radical chemistry in the troposphere, Chem. Soc. Rev., 34, 376-395, 2005.

Penkett, S. A., Monks, P. S., Carpenter, L. J., and Clemitshaw, K. C.: Relationships between ozone photolysis rates and peroxy radical concentrations in clean air over the Southern Ocean, J. Geophys. Res., 102, 12 805-12 817, 1997.

Penkett, S. A., Clemitshaw, K. C., Savage, N. H., Burgess, R. A., Cardenas, L. M., Carpenter, L. J., McFadyen, G. G., and Cape, J. N.: Studies of oxidant production at the Weybourne Atmospheric Observatory in summer and winter conditions, J. Atmos. Chem., 33, 111-128, 1999.

Reeves, C. E., Penkett, S. A., Bauguitte, S., Law, K. S., Evans, M. J., Bandy, B. J., Monks, P. S., Edwards, G. D., Phillips, G., Barjat, H., Kent, J., Dewey, K., Schmitgen, S., and Kley, D.: Potential for Photochemical Ozone Formation in the Troposphere over the North Atlantic as derived from Aircraft Observations during ACSOE, J. Geophys. Res. (Atmos)., 107, 4707, doi:10.1029/2002JD002415, 2002.

Ridley, B. A., Madronich, S., Chatfield, R. B., Walega, J. G., Shetter, R. E., Carroll, M. A., and Montzka, D. D.: Measurements and model simulations of the phototstationary state during Mauna Loa Observatory Photochemistry Experiment: Implications for radical concentrations and ozone production and loss rates, J.
Geophys. Res., 97, 10375-10388, 1992.

Salisbury, G.: Measurement of peroxy radicals in the marine boundary layer, Ph.D. thesis, University of Leicester, 2001.

Salisbury, G., Rickard, A. R., Monks, P. S., Allan, B. J., Bauguitte, S., Penkett, S. A., Carslaw, N., Lewis, A. C., Creasy, D. J., Heard, D. E., Jacobs, P. J., and Lee, J. D.: Production of peroxy radicals at night via reactions of ozone and the nitrate radical in the marine boundary layer, J. Geophys. Res., 106, 12 669-12 687, 2001.

Salisbury, G., Monks, P. S., Bauguitte, S. Bandy, B. J., and Penkett, S. A.: A seasonal comparison of the ozone photochemistry in clean and polluted air masses at Mace Head, Ireland, J. Atmos. Chem., 41, 163-187, 2002.

Seroji, A., Webb, A., Coe, H., Monks, P. S., and Rickard, A. R.: A comparison between the derived photolysis rates of $\mathrm{O}_{3}, \mathrm{NO}_{2}$ and $\mathrm{CH}_{2} \mathrm{O}$ from GUV-541 radiometer with the photolysis rates measured by a spectroradiometer and filter radiometers, J. Geophys. Res., 109, D21307, doi:10.1029/2003JD004674, 2004.

Shetter, R. E., Junkermann, W., Swartz W. H., Frost, G. J., Crawford, J. H., Lefer, B. L., Barrick, J. D., Hall, S. R., Hofzumahaus, A., Bais, A., Calvert, J. G., Cantrell, C. A., Madronich, S., Müller, M., Kraus, A., Monks, P. S., Edwards, G. D., McKenzie, R. Johnston, P., Schmitt, R., Griffioen, E., Krol, M., Kylling, A., Dickerson, R. R., Lloyd, S. A., Martin, T., Gardiner, B., Mayer, B., Pfister, G., Röth, E.-P., Köpke, P., Ruggaber, A., Schwander, H., and van Weele, M.: Photolysis frequency of $\mathrm{NO}_{2}$ : Measurement and modeling during the International Photolysis Frequency Measurement and Modeling Intercomparison (IPMMI), J. Geophys. Res., 108, 8544, doi:10.1029/2002JD002932, 2003.

Sillman, S. and He, D.: Some theoretical results concerning $\mathrm{O}_{3}-$ $\mathrm{NO}_{\mathrm{x}}$-VOC chemistry and $\mathrm{NO}_{\mathrm{x}}$-VOC indicators, J. Geophys. Res., 107, 4659-4672, 2002.

Solberg, S., Dye, C., Walker, S.-M., and Simpson, D.: Long-term measurements and model calculations of formaldehyde at rural European monitoring sites, Atmos. Environ., 35, 195-207, 2001.

Stroud, C., Madronich, S., Atlas, E., Cantrell, C., Fried, A., Wert, B., Ridley, B., Eisele, F., Mauldin, L., Shetter, R., Lefer, B., Flocke, F., Weinheimer, A., Coffey, M., Heikes, B., Talbot, R., and Blake, D.: Photochemistry in the Arctic Free Troposphere: Ozone Budget and Its Dependence on Nitrogen Oxides and the Production Rate of Free Radicals, J. Atmos. Chem., 47, 107-138, 2004.

Yang, J., Honrath, R. E., Peterson, M. C., Dibb, J. E., Sumner, A. L., Shepson, P. B., Frey, M., Jacobi, H.-W., Swanson, A., and Blake, N.: Impacts of snow pack emissions on deduced levels of $\mathrm{OH}$ and peroxy radicals at Summit, Greenland, Atmos. Environ., 36, 2523-2534, 2002.

Yang, J., Honrath, R. E., Peterson, M. C., Parrish, D. D., and Warshawsky, M.: Photostationary state deviation-estimated peroxy radicals and their implications for $\mathrm{HO}_{x}$ and ozone photochemistry at a remote northern Atlantic coastal site, J. Geophys. Res., 109, D02312, doi:10.1029/2003JD003983, 2004.

Yienger, J. J., Klonecki, A. A., Levy, H., Moxim, W. J., and Carmichael, G. R.: An evaluation of chemistry's role in the winter-spring ozone maximum found in the northern mid-latitude free troposphere, J. Geophys. Res., 104, 3655-3667, 1999.

Volz-Thomas, A., Pätz, H.-W., Houben, N., Konrad, S., Mihelcic, D.,: Inorganic trace gases and peroxy radicals during BERLIOZ at Pabstthum: An investigation of the photostationary state of $\mathrm{NO}_{\mathrm{x}}$ and $\mathrm{O}_{3}$, J. Geophys. Res., 108, 8248, 
doi:10.1029/2001JD001255, 2003.

Zanis, P., Monks, P. S., Green, T. J., Schuepbach, E., Carpenter, L. J., Mills, G. P., Rickard, A. R., Brough, N., and Penkett, S. A.: Seasonal variation of peroxy radicals in the lower free troposphere based on observations from the FREE Tropospheric EXperiments in the Swiss Alps, Geophys. Res. Lett., 30, 1497, doi:10.1029/2003GL017122, 2003.
Zenker, T., Fischer, H., Nikitas, C., Parchatka, U., Harris, G. W., Mihelcic, D., Müsgen, P., Pätz, H. W., Schultz, M., VolzThomas, A., Schmitt, R., Behmann, T., Weissenmayer, M., and Burrows, J. P. :Intercomparison of $\mathrm{NO}, \mathrm{NO}_{2}, \mathrm{NO}_{\mathrm{y}}, \mathrm{O}_{3}$ and $\mathrm{RO}_{x}$ measurements during the Oxidising Capacity of the Tropospheric Atmosphere (OCTA) campaign 1993 at Izana, J. Geophys. Res., 103, 13 615-13 634, 1998. 